\title{
Molecular signature of anastasis for reversal of apoptosis
}

\section{[version 1; peer review: 1 approved, 1 approved with}

\section{reservations]}

\author{
Ho Man Tang1 , C. Conover Talbot Jr¹, Ming Chiu Fung², Ho Lam Tang (iD)3 \\ ${ }^{1}$ Institute for Basic Biomedical Sciences, Johns Hopkins University School of Medicine, Baltimore, USA \\ ${ }^{2}$ School of Life Sciences, Chinese University of Hong Kong, Hong Kong, Hong Kong \\ ${ }^{3}$ W. Harry Feinstone Department of Molecular Microbiology and Immunology, Johns Hopkins University Bloomberg School of Public \\ Health, Baltimore, USA
}

V1 First published: 13 Jan 2017, 6:43
https://doi.org/10.12688/f1 000research.10568.1

Latest published: 09 Feb 2017, 6:43

https://doi.org/10.12688/f1000research.10568.2

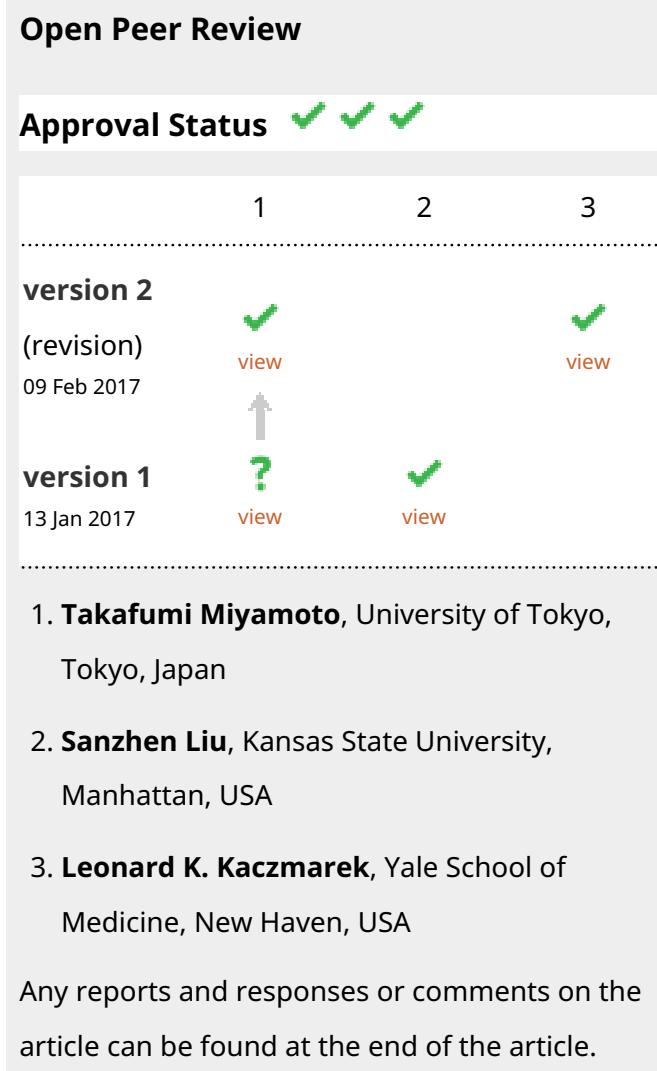

1

2

3

version 2

(revision)

09 Feb 2017

version 1

13 Jan 2017

$\checkmark \checkmark$

$\ldots$

3

1. Takafumi Miyamoto, University of Tokyo,

Tokyo, Japan

2. Sanzhen Liu, Kansas State University,

Manhattan, USA

3. Leonard K. Kaczmarek, Yale School of Medicine, New Haven, USA

Any reports and responses or comments on the article can be found at the end of the article. 
Corresponding authors: Ho Man Tang (homantang@jhmi.edu), Ming Chiu Fung (mingchiufung@cuhk.edu.hk), Ho Lam Tang ( holamtang@jhmi.edu)

Competing interests: No competing interests were disclosed.

Grant information: This work was supported by the Life Science Research Foundation fellowship (H.L.T.).

The funders had no role in study design, data collection and analysis, decision to publish, or preparation of the manuscript.

Copyright: ( 2017 Tang HM et al. This is an open access article distributed under the terms of the Creative Commons Attribution License , which permits unrestricted use, distribution, and reproduction in any medium, provided the original work is properly cited.

How to cite this article: Tang HM, Talbot Jr CC, Fung MC and Tang HL. Molecular signature of anastasis for reversal of apoptosis [version 1; peer review: 1 approved, 1 approved with reservations] F1000Research 2017, 6:43

https://doi.org/10.12688/f1000research.10568.1

First published: 13 Jan 2017, 6:43 https://doi.org/10.12688/f1000research.10568.1 


\section{Introduction}

Apoptosis (Greek for "falling to death") was generally assumed to be an irreversible cell suicide process because it involves rapid and massive cell destruction ${ }^{1-7}$. During apoptosis, intrinsic and extrinsic pro-apoptotic signals can converge at mitochondria, leading to mitochondrial outer membrane permeabilization (MOMP), which releases cell execution factors, such as cytochrome $c$ to trigger activation of apoptotic proteases including caspase-3 and $-7^{8,9}$, small mitochondria-derived activator of caspases (Smac)/direct IAP binding protein with low pI (DIABLO) to eliminate inhibitor of apoptosis protein (IAP) inhibition of caspase activation ${ }^{10,11}$, and apoptosis-inducing factor (AIF) and endonuclease $G$ to destroy DNA ${ }^{12-15}$. Activated caspases commit cells to destruction by cleaving hundreds of functional and structural cellular substrates $^{2,16}$. Crosstalk between signalling pathways amplify the caspase cascade to mediate cell demolition via nucleases (DNA fragmentation factor $[\mathrm{DFF}] /$ caspase-activated DNase $[\mathrm{CAD}]$ ) to further destroy the genome ${ }^{17-19}$, and alter lipid modifying enzymes to cause membrane blebbing and apoptotic body formation ${ }^{20,21}$. Therefore, cell death is considered to occur after caspase activation within a few minutes ${ }^{22,23}$.

However, we and other groups have demonstrated reversal of early stage apoptosis, such as externalization of phosphatidylserine (PS) in cultured primary cells and cancer cell lines ${ }^{24-27}$. We have further demonstrated that dying cells can reverse apoptosis even after reaching the generally assumed "point of no return", such as MOMP-mediated cytochrome $c$ release, caspase activation, DNA damage, nuclear fragmentation, and apoptotic body formation ${ }^{26-28}$. Our observation of apoptosis reversal at late stages is further supported by an independent study, which shows recovery of cells after MOMP $^{29}$. To detect reversal of apoptosis in live animals, we have further developed a new in vivo caspase biosensor, designated "CaspaseTracker"30, and successfully identified and tracked somatic, germ and stem cells to survive transiently-induced cell death, and potentially during normal development and homeostasis in Drosophila melanogaster after caspase activation ${ }^{30,31}$, the hallmark of apoptosis ${ }^{2,32}$. We refer to this recovery phenomenon as "anastasis" 27 , which means "rising to life" in Greek, for the reversal of apoptosis. Anastasis appears to be an intrinsic cell survival phenomenon, as removal of cell death stimuli is sufficient to allow dying cells to recover ${ }^{26-28,30}$.

The physiological, pathological and therapeutic importance of anastasis is not yet known. We proposed that anastasis could be an unexpected tactic that cancer cells use to escape cancer therapy ${ }^{26-28}$. Many tumours undergo dramatic initial responses to cell death-inducing radiation or chemotherapy ${ }^{33-36}$; however, these cells relapse, and metastasis often occurs in most types of cancer $^{33-35}$. Therefore, the ability of cells to recover from transient induction of cell death may allow tumour cells to escape treatment, and survive and proliferate, resulting in relapse ${ }^{26-28}$. Furthermore, cells may acquire new oncogenic mutations and transformation phenotypes during anastasis ${ }^{27,28}$, such as DNA damage caused by apoptotic nucleases. Therefore, anastasis could be one mechanism underlying the observation that repeated tissue injury increases the risk of cancer in a variety of tissues ${ }^{37}$, such as liver damage due to alcoholism ${ }^{38}$, chronic thermal injury in the oesophagus induced by the consumption of very hot beverages ${ }^{39-41}$, evolution of drug resistance in recurrent cancers ${ }^{26-28}$, and development of a second cancer during subsequent therapy ${ }^{42-45}$. Anastasis can also occur in primary cardiac cells and neuronal cell lines ${ }^{27,28}$, and potentially in cardiomyocytes in vivo following transient ischemia ${ }^{46}$. These findings suggest anastasis as an unexpected cellular protective mechanism. Therefore, uncovering the mechanisms of anastasis may provide new insights into the regulation of cell death and survival, and harnessing this mechanism via suppression or promotion of anastasis would aid treatment of intractable diseases including cancer, heart failure and neurodegeneration.

Our previous study demonstrated reversibility of ethanol-induced apoptosis at late stages in mouse primary liver cells, and revealed that new transcription is important to reverse apoptosis ${ }^{27,28}$. During recovery, there was up-regulation of genes involved in pro-survival pathways and DNA damage responses during anastasis (Bag3, Mcl1, Dnajb1, Dnajb9, Hsp90aa1, Hspa1b, and Hspb1, Mdm2) ${ }^{27}$. Interestingly, inhibiting some of those genes by corresponding specific chemical inhibitors significantly suppresses anastasis ${ }^{27}$. However, the molecular mechanism of anastasis remains to be elucidated. To study the cellular processes of anastasis, we performed time-course RNA microarray analysis to determine the gene expression profiles of cultured mouse primary liver cells undergoing anastasis following exposure to ethanol, and identified unique gene expression patterns during reversal of apoptosis. Here, we present our time-course microarray data, which reveals the molecular signature of anastasis.

\section{Methods}

RNA isolation, reverse transcription, and microarray

Mouse primary liver cells were isolated from BALB/c mice using collagenase $\mathrm{B}$ and cultured as described ${ }^{27,47}$. The cells were treated with $4.5 \%$ ethanol in DMEM/F-12 (DMEM:nutrient mixture F-12) supplemented with $10 \%$ fetal bovine serum, $100 \mathrm{U} / \mathrm{ml}$ penicillin, and $100 \mu \mathrm{g} / \mathrm{ml}$ streptomycin (Life Technologies, Carlsbad, CA, USA) at $37^{\circ} \mathrm{C}$ under an atmosphere of $5 \% \mathrm{CO}$ $2 / 95 \%$ airfor 5 hours (R0), and then washed and further incubated in fresh culture medium for 3 hours (R3), 6 hours (R6), 24 hours (R24), and 48 hours (R48). Three biological replicates were performed at each time point. The untreated cells served as control (Ctrl). Total RNA in the corresponding cell conditions was harvested using TRIzol Reagent, and RNA was purified using the RNeasy Mini Kit (Qiagen, Cologne, Germany). Reverse transcription was performed using SABiosciences C-03 RT ${ }^{2}$ First Strand Kit to construct cDNA (SABiosciences-Qiagen, Frederick, MD, USA). The cDNA samples were analysed using the Illumina MouseWG-6 v2.0 Expression BeadChip (Illumina, San Diego, CA, USA).

\section{Gene expression data analysis}

The Partek Genomics Suite 6.6 (Partek, St. Louis, MO, USA) was used for principal component analysis ${ }^{48}$. Spotfire DecisionSite 9.1.2 (TIBCO, Palo Alto, CA, USA) platform was used to evaluate the fold change of gene expression levels between time points when compared with a common starting point ${ }^{49}$. Signal values were converted into $\log _{2}$ space and quality control tests were performed to ensure data integrity by comparing the signals of the three biological replicates at each time point. The fold change was based on averaged values of the three replicates at each 
time point; two-sample Student's $t$-test was used to determine statistical significance as $p$-values of less than 0.05, using Partek Genomics Suite v6.5 (Partek Inc., St. Louis, MO, USA).

For the time-course gene expression analysis using Spotfire, all time points were compared with time point $\mathrm{Ctrl}$, which represents untreated cells. Spotfire was used to show the genes that displayed specific changes in gene expression after removal of apoptotic inducers for 3 hours and 6 hours, as well as the genes that were up-regulated from apoptosis (R0) to 6 hours (R6) after removal of the inducer. Genes with specific and significant change $\left(\log _{2}>1\right.$ or $\left.<-1\right)$ in expression at the corresponding timepoint are highlighted. Interaction network analysis of the up-regulated genes during anastasis was performed using GeneMANIA database (http://genemania.org/) $)^{50,51}$.

\section{Results and discussion}

We have demonstrated that mouse primary liver cells can reverse the apoptotic process at the execution stage, despite experiencing important checkpoints commonly believed to be the "point of no return", including caspase-3 activation, DNA damage, and cell shrinage ${ }^{27,28}$. To pursue the mechanisms of anastasis, we performed time-course high-throughput microarray to evaluate gene expression profiles during reversal of ethanol-induced apoptosis in mouse primary liver cells. RNA samples were collected from the untreated primary liver cells $(\mathrm{Ctrl})$, the cells treated with $4.5 \%$ ethanol for 5 hours when cells exhibited hallmarks of apoptosis (R0), and the treated cells that were then washed and cultured in fresh medium for 3 (R3), 6 (R6), 24 (R24) and 48 (R48) hours. Apoptosis was confirmed previously in the ethanol-treated cells (R0), which displaced hallmarks of apoptosis, including plasma membrane blebbing, cell shrinkage, cleavage of caspase- 3 and its substrates, such as PARP and ICAP (Figure 1A and B, images reprinted with permission ${ }^{27}$ ). The features of apoptosis vanished after removal of the cell death inducer (R24), indicating recovery of the cells (Figure 1A and B). Three biological replicates were performed at each time point. Principal component analysis indicated that all three biological replicates of each time point exhibited a very high correlation, as indicated by clustering, for the dataset of all 18 samples (Figure 2A; see Data availability ${ }^{52}$ ). Unsupervised hierarchical clustering confirms the similarity between all the replicates at each time point (Figure 2B; see Data availability ${ }^{52}$; Supplementary Figure 1).

Genes that display significant changes in expression during anastasis at the earliest time point of 3 hours, following the removal of the apoptotic inducer, may represent critical first responders of anastasis (Figure 3A, Table 1), including transcription factors of the activator protein-1 (AP-1) family (Atf3, Fos, Fosb, Jun, Junb), transforming growth factor- $\beta$ (TGF- $\beta$ ) signal pathway and its related regulators (Inhba, Snai1, Tgif1, Sox4, Klf4, Klf6, Klf9), prosurvival Bcl-2 family member (Bag3), inhibitor of p53 (Mdm2), anti-proliferation (Btg1), DNA damage (Ddit3, Ddit4) and stressinducible (Dnajb1, Dnajb9, Herpud1, Hspb1, Hspa1b) responses. Starting at 6 hours of anastasis, other groups of gene pathways displace the peak of transcription, such as cell cycle arrest (Cdkn1a, Trp53inp1), autophagy (Atg12, Vps37b), and cell migration (Mmp10 and Mmp13) (Figure 3B, Table 2 and Table 3). Expression of potent angiogenic factors, such as Vegfa and Angptl4, peaks at 3 and 6 hours of anastasis, respectively. Changes in expression of most of these genes peak at the 3-6-hour time points after removal of the apoptotic stimulus and then return to baseline (Figure 3A and B; Supplementary Figure 1). Interestingly, certain genes involve in splicing of pre-mRNA (Rnu6), and growth arrest and DNA repair (Gadd45g) stay up-regulated during both apoptosis and anastasis (Figure 3C; Supplementary Figure 1).

A
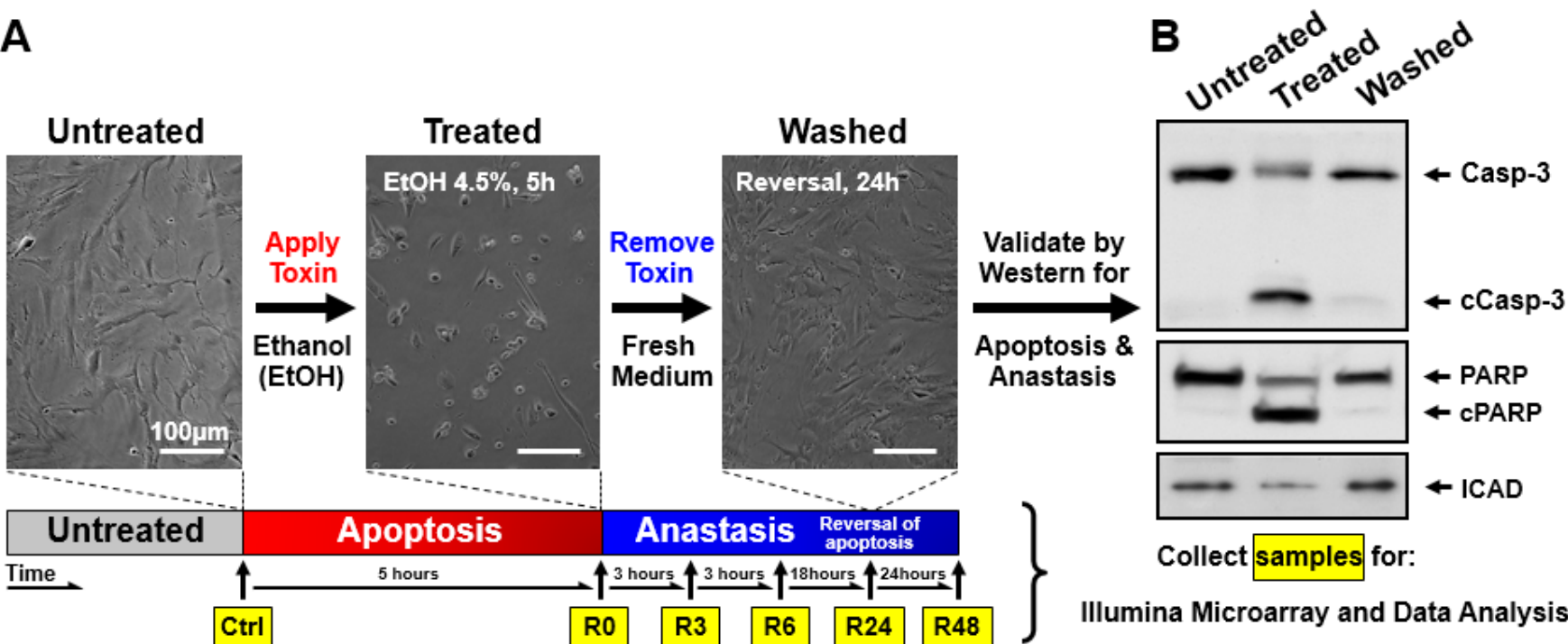

Illumina Microarray and Data Analysis

Figure 1. Flow chart for experimental design. Mouse primary liver cells were treated with $4.5 \%$ ethanol for 5 hours (R0) and then washed and cultured in fresh medium for 3 (R3), 6 (R6), 24 (R24), and 48 (R48) hours. The untreated cells served as control (Ctrl). (A) Light microscopy and (B) western blot analysis validated apoptosis to occur at R0, and anastasis at R24. Cells were collected at the indicated timepoints of (A) for RNA extraction. Gene expression profiling was performed by microarray, and analysed by Spotfire. The images from Figure $1 A$ and B are adopted from the Mol Biol Cell 23, 2240-52 (2012) ${ }^{27}$. Reprinted with permission. 


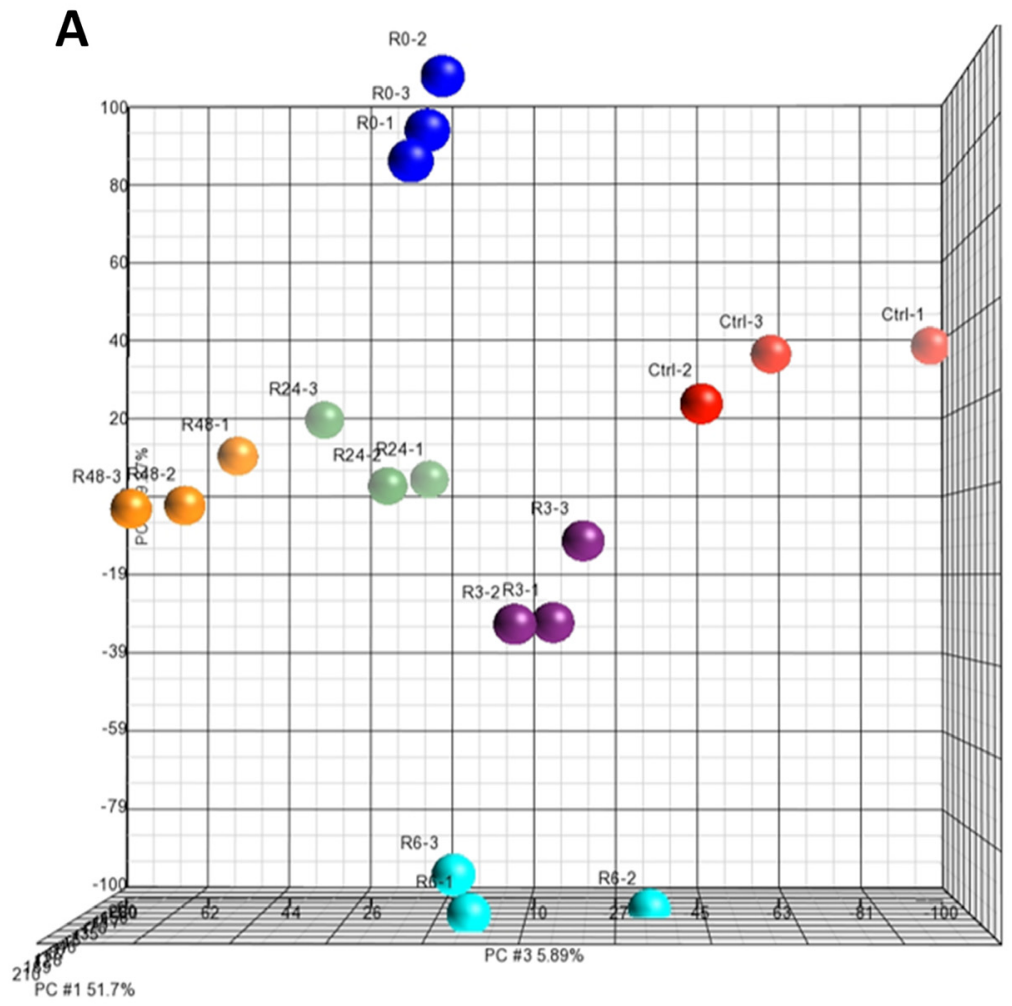

B

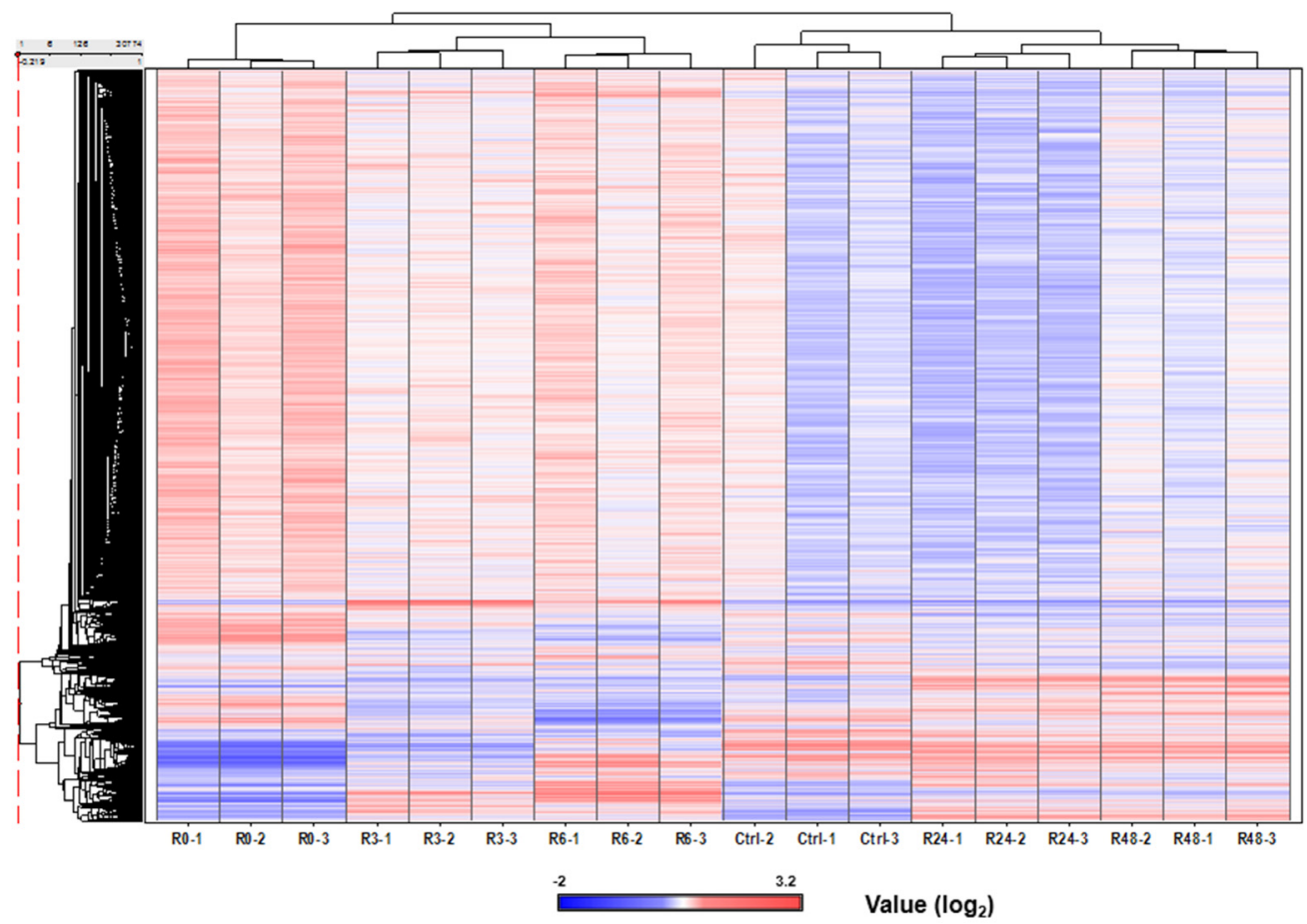

Figure 2. Technical validation of microarray data. The three biological replicate samples of microarray data were shown to cluster together by using (A) principal component analysis (PCA) and (B) unsupervised hierarchical clustering of the RNA microarray data of eighteen samples. 

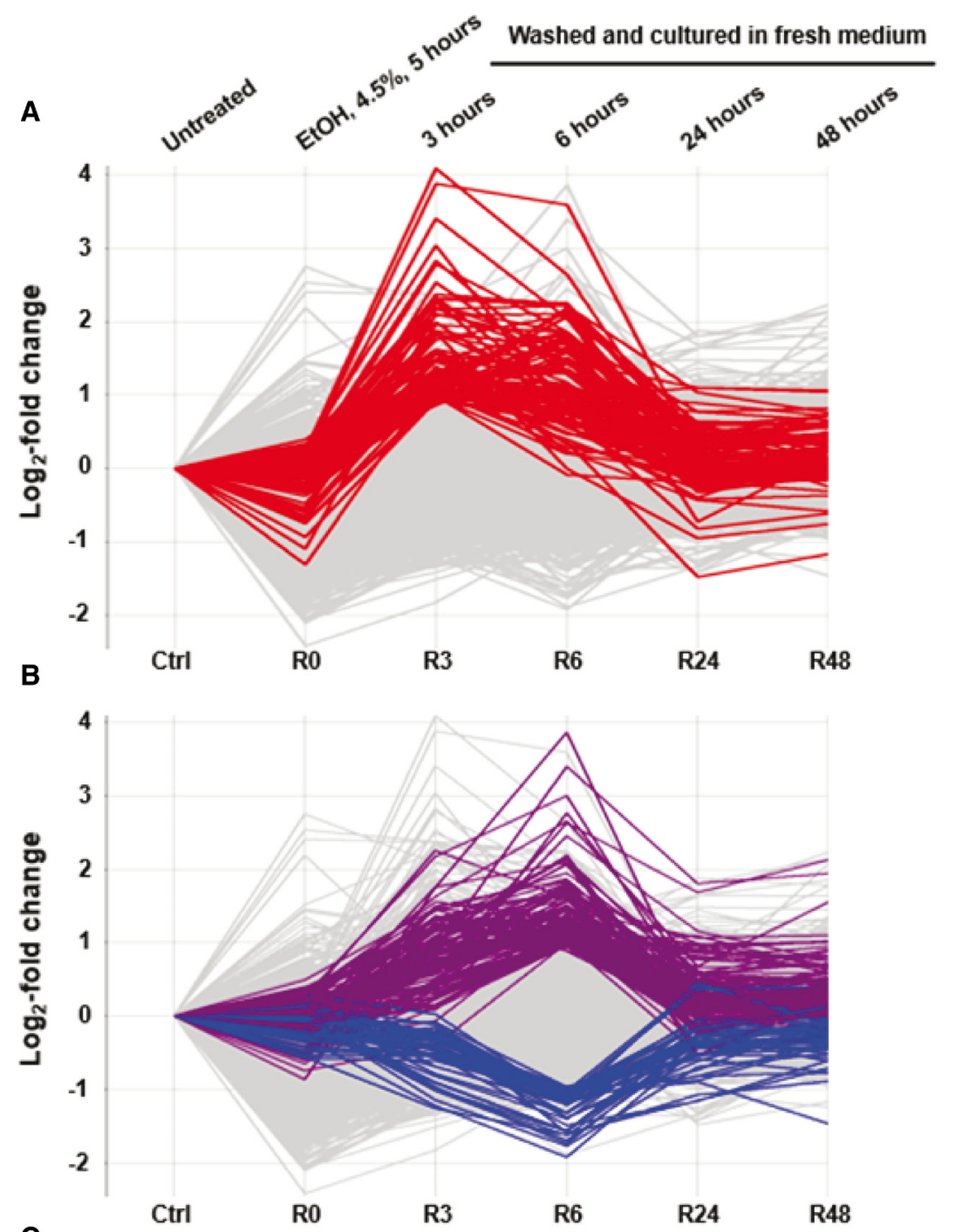

C

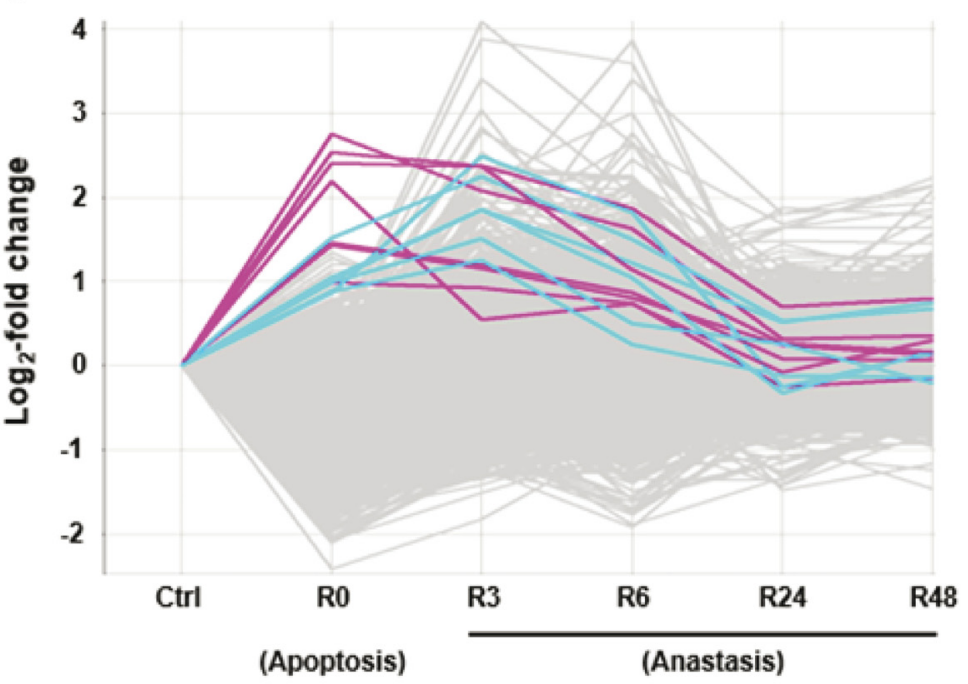

Figure 3. Change of gene expression profiles during reversal of apoptosis. Log $_{2}$ fold change of gene expression comparison between untreated cells (Ctrl), ethanol-induced apoptotic cells (RO), and induced cells that were then washed and further cultured in fresh medium for 3 (R3), 6 (R6), 24 (R24), and 48 (R48) hours. Genes that displaced specific (A) up-regulation at R3, (B) up- or down-regulation, and (C) up-regulation during $\mathrm{RO}$ to $\mathrm{R} 6$ absolute $\log _{2}$ fold change $>1$ are highlighted. The $\log _{2}$ signal values from three biological replicates were averaged (geometric mean) for each time point. 
Table 1. List of top 67 up-regulated genes at $3^{\text {rd }}$ hour (R3) of anastasis, with $\log _{2}$ fold change $>1$, compared with Ctrl (untreated cells).

\begin{tabular}{|c|c|c|c|c|}
\hline $\begin{array}{l}\text { Sort } \\
\text { Order }\end{array}$ & Gene Symbol & Definition & Accession & $\begin{array}{l}\log _{2} \text { fold change } \\
\text { R3 vs. Ctrl }\end{array}$ \\
\hline 1 & Atf3 & activating transcription factor 3 & NM_007498.2 & 4.08867 \\
\hline 2 & Hspa1b & heat shock protein $1 \mathrm{~B}$ & NM_010478.2 & 3.88264 \\
\hline 3 & Fosb & FBJ osteosarcoma oncogene B & NM_008036.2 & 3.40725 \\
\hline 4 & Fos & FBJ osteosarcoma oncogene & NM_010234.2 & 3.03649 \\
\hline 5 & Egr2 & no definition & NM_010118.1 & 2.82862 \\
\hline 6 & Dnajb1 & DnaJ (Hsp40) homolog, subfamily B, member 1 & NM_018808.1 & 2.78017 \\
\hline 7 & Dusp1 & dual specificity phosphatase 1 & NM_013642.2 & 2.533 \\
\hline 8 & Sox9 & SRY-box containing gene 9 & NM_011448.2 & 2.37421 \\
\hline 9 & Zfp36 & zinc finger protein 36 & NM_011756.4 & 2.33651 \\
\hline 10 & Mfsd11 & no definition & AK007898 & 2.31434 \\
\hline 11 & Hspb1 & no definition & NM_013560 & 2.30989 \\
\hline 12 & Jun & Jun oncogene & NM_010591.1 & 2.28214 \\
\hline 13 & Ddit4 & DNA-damage-inducible transcript 4 & NM_029083.1 & 2.25327 \\
\hline 14 & Vegfa & $\begin{array}{l}\text { vascular endothelial growth factor A (Vegfa), } \\
\text { transcript variant } 1\end{array}$ & NM_001025250.2 & 2.19637 \\
\hline 15 & Herpud1 & $\begin{array}{l}\text { homocysteine-inducible, ER stress-inducible, } \\
\text { ubiquitin-like domain member } 1\end{array}$ & NM_022331.1 & 2.17913 \\
\hline 16 & Ddit3 & DNA-damage inducible transcript 3 & NM_007837.2 & 2.16334 \\
\hline 17 & Mdm2 & transformed mouse 3T3 cell double minute 2 & NM_010786.3 & 2.11273 \\
\hline 18 & Chac1 & ChaC, cation transport regulator-like 1 & NM_026929.3 & 2.08317 \\
\hline 19 & Arc & activity regulated cytoskeletal-associated protein & NM_018790.2 & 1.99046 \\
\hline 20 & Dnajb9 & DnaJ (Hsp40) homolog, subfamily B, member 9 & NM_013760.4 & 1.961 \\
\hline 21 & Zfand2a & zinc finger, AN1-type domain 2A & NM_133349.2 & 1.8778 \\
\hline 22 & Hes1 & hairy and enhancer of split 1 & NM_008235.2 & 1.85536 \\
\hline 23 & Bag3 & BCL2-associated athanogene 3 & NM_013863.4 & 1.85303 \\
\hline 24 & LOC100048331 & $\begin{array}{l}\text { PREDICTED: similar to DnaJ (Hsp40) homolog, } \\
\text { subfamily A, member } 4\end{array}$ & XR_034509.1 & 1.82115 \\
\hline 25 & Hmox1 & heme oxygenase & NM_010442.1 & 1.82111 \\
\hline 26 & Hspa5 & heat shock protein 5 & NM_022310.2 & 1.8205 \\
\hline 27 & Dlx2 & distal-less homeobox 2 & NM_010054.1 & 1.62035 \\
\hline 28 & 6430590I03Rik & no definition & XM_489535 & 1.61804 \\
\hline 29 & Junb & Jun-B oncogene (Junb) & NM_008416.1 & 1.61245 \\
\hline 30 & LOC381140 & no definition & XM_355056.1 & 1.57312 \\
\hline 31 & 5430411C19Rik & PREDICTED: RIKEN cDNA 5430411C19 gene & XM_001478639.1 & 1.56805 \\
\hline 32 & Hspa1a & no definition & NM_010479 & 1.56028 \\
\hline
\end{tabular}




\begin{tabular}{|c|c|c|c|c|}
\hline $\begin{array}{l}\text { Sort } \\
\text { Order }\end{array}$ & Gene Symbol & Definition & Accession & $\begin{array}{l}\log _{2} \text { fold change } \\
\text { R3 vs. Ctrl }\end{array}$ \\
\hline 33 & Csrnp1 & AXIN1 up-regulated 1 & NM_153287.3 & 1.46632 \\
\hline 34 & Tnfaip3 & tumor necrosis factor, alpha-induced protein 3 & NM_009397.2 & 1.45772 \\
\hline 35 & LOC100048105 & PREDICTED: similar to Ubc protein, transcript variant 1 & XM_001479832.1 & 1.45617 \\
\hline 36 & Bhlhe40 & basic helix-loop-helix domain containing, class B2 & NM_011498.4 & 1.39137 \\
\hline 37 & Dyrk3 & $\begin{array}{l}\text { dual-specificity tyrosine-(Y)-phosphorylation regulated } \\
\text { kinase } 3\end{array}$ & NM_145508.2 & 1.3612 \\
\hline 38 & Egr1 & early growth response 1 & NM_007913.5 & 1.35873 \\
\hline 39 & Klf9 & PREDICTED: RIKEN cDNA $2310051 E 17$ gene & XM_001479552.1 & 1.35306 \\
\hline 40 & Snai1 & snail homolog 1 & NM_011427.2 & 1.35105 \\
\hline 41 & Dusp2 & dual specificity phosphatase 2 & NM_010090.2 & 1.34955 \\
\hline 42 & Ubg & no definition & no accession & 1.3258 \\
\hline 43 & BC022687 & cDNA sequence $\mathrm{BC} 022687$ & NM_145450.3 & 1.31366 \\
\hline 44 & Btg1 & B-cell translocation gene 1, anti-proliferative & NM_007569.1 & 1.2996 \\
\hline 45 & LOC100046232 & $\begin{array}{l}\text { PREDICTED: similar to NFIL3/E4BP4 transcription } \\
\text { factor }\end{array}$ & XM_001475817.1 & 1.27509 \\
\hline 46 & Hsph1 & no definition & NM_013559.1 & 1.2662 \\
\hline 47 & Hist1h2ae & histone cluster 1, H2ae & NM_178187.3 & 1.26359 \\
\hline 48 & mtDNA_ND4L & no definition & no accession & 1.2474 \\
\hline 49 & Dnajb4 & DnaJ (Hsp40) homolog, subfamily B, member 4 & NM_025926.1 & 1.24227 \\
\hline 50 & Klf4 & Kruppel-like factor 4 & NM_010637.1 & 1.23324 \\
\hline 51 & Tgif1 & TGFB-induced factor homeobox 1 & NM_009372.2 & 1.22645 \\
\hline 52 & KIf6 & Kruppel-like factor 6 & NM_011803.2 & 1.22027 \\
\hline 53 & Ppp1r10 & protein phosphatase 1 , regulatory subunit 10 & NM_175934.2 & 1.21047 \\
\hline 54 & Gm16516 & no definition & NM_025293.1 & 1.20916 \\
\hline 55 & Ifrd1 & interferon-related developmental regulator 1 & NM_013562.1 & 1.19232 \\
\hline 56 & Slc23a3 & $\begin{array}{l}\text { solute carrier family } 23 \text { (nucleobase transporters), } \\
\text { member } 3\end{array}$ & NM_194333.3 & 1.18765 \\
\hline 57 & Mfsd11 & major facilitator superfamily domain containing 11 & NM_178620.3 & 1.16606 \\
\hline 58 & Gm4589 & PREDICTED: hypothetical protein LOC100045678 & XM_001475512.1 & 1.16498 \\
\hline 59 & Klf9 & Kruppel-like factor 9 & NM_010638.4 & 1.12553 \\
\hline 60 & Siah2 & seven in absentia 2 & NM_009174.3 & 1.11181 \\
\hline 61 & Map1lc3b & microtubule-associated protein 1 light chain 3 beta & NM_026160.3 & 1.10454 \\
\hline 62 & Plk2 & polo-like kinase 2 & NM_152804.1 & 1.05963 \\
\hline 63 & Fgf21 & fibroblast growth factor 21 & NM_020013.4 & 1.05538 \\
\hline 64 & Id4 & inhibitor of DNA binding 4 & NM_031166.2 & 1.04488 \\
\hline 65 & Csf1 & colony stimulating factor 1 & NM_007778.3 & 1.03533 \\
\hline 66 & $\mathrm{Bbc3}$ & BCL2 binding component 3 (Bbc3) & NM_133234.1 & 1.03288 \\
\hline 67 & 6230400G14Rik & no definition & no accession & 1.02327 \\
\hline
\end{tabular}


Table 2. List of top 109 up-regulated genes at $6^{\text {th }}$ hour (R6) of anastasis, with $\log _{2}$ fold change $>0.93$, compared with Ctrl (untreated cells).

\begin{tabular}{|c|c|c|c|c|}
\hline $\begin{array}{l}\text { Sort } \\
\text { Order }\end{array}$ & Gene Symbol & Definition & Accession & $\begin{array}{c}\log _{2} \text { fold change } \\
\text { R6 vs. Ctrl }\end{array}$ \\
\hline 1 & Inhba & inhibin beta-A & NM_008380.1 & 3.86584 \\
\hline 2 & Mmp10 & matrix metallopeptidase 10 & NM_019471.2 & 3.39644 \\
\hline 3 & Lce1f & late cornified envelope $1 \mathrm{~F}$ & NM_026394.2 & 2.99957 \\
\hline 4 & Serpinb2 & serine (or cysteine) peptidase inhibitor, clade B, member 2 & NM_011111.3 & 2.77022 \\
\hline 5 & Serpina3h & serine (or cysteine) peptidase inhibitor, clade $\mathrm{A}$, member $3 \mathrm{H}$ & NM_001034870.2 & 2.65107 \\
\hline 6 & Mmp13 & matrix metallopeptidase 13 & NM_008607.1 & 2.62637 \\
\hline 7 & Ptpn22 & protein tyrosine phosphatase, non-receptor type 22 & NM_008979.1 & 2.45292 \\
\hline 8 & Rgs16 & regulator of G-protein signaling 16 & NM_011267.2 & 2.18647 \\
\hline 9 & Nppb & natriuretic peptide precursor type B & NM_008726.3 & 2.15071 \\
\hline 10 & Has1 & hyaluronan synthase 1 & NM_008215.1 & 2.14235 \\
\hline 11 & Dusp5 & no definition & XM_140740.3 & 2.09536 \\
\hline 12 & Sqstm1 & sequestosome 1 & NM_011018.2 & 2.07477 \\
\hline 13 & Nupr1 & nuclear protein 1 & NM_019738.1 & 2.06313 \\
\hline 14 & Sphk1 & sphingosine kinase 1 (Sphk1), transcript variant 2 & NM_025367.5 & 1.94856 \\
\hline 15 & Dusp4 & dual specificity phosphatase 4 & NM_176933.4 & 1.85742 \\
\hline 16 & KIhl21 & kelch-like 21 & NM_001033352.3 & 1.84531 \\
\hline 17 & Lor & loricrin & NM_008508.2 & 1.81763 \\
\hline 18 & Ndrg1 & $\mathrm{N}$-myc downstream regulated gene 1 & NM_008681.2 & 1.79158 \\
\hline 19 & Srxn1 & sulfiredoxin 1 homolog & NM_029688.4 & 1.78335 \\
\hline 20 & Hk2 & PREDICTED: hypothetical protein LOC100047934 & XM_001478074.1 & 1.7519 \\
\hline 21 & Txnrd1 & thioredoxin reductase 1 (Txnrd1), transcript variant 1 & NM_001042523.1 & 1.75148 \\
\hline 22 & Angptl4 & no definition & NM_020581 & 1.72982 \\
\hline 23 & Trib3 & tribbles homolog 3 & NM_175093.2 & 1.72246 \\
\hline 24 & C330006P03Rik & no definition & no accession & 1.71297 \\
\hline 25 & Cdkn1a & cyclin-dependent kinase inhibitor $1 \mathrm{~A}$ & NM_007669.2 & 1.69118 \\
\hline 26 & Gdf15 & growth differentiation factor 15 & NM_011819.1 & 1.67887 \\
\hline 27 & Prkg2 & protein kinase, cGMP-dependent, type II & NM_008926.3 & 1.67374 \\
\hline 28 & H2afj & $\mathrm{H} 2 \mathrm{~A}$ histone family, member $\mathrm{J}$ & NM_177688.2 & 1.64825 \\
\hline 29 & Hbegf & heparin-binding EGF-like growth factor & NM_010415.1 & 1.61893 \\
\hline 30 & Trp53inp1 & transformation related protein 53 inducible nuclear protein 1 & NM_021897.1 & 1.61348 \\
\hline 31 & Gfpt2 & glutamine fructose-6-phosphate transaminase 2 & NM_013529.2 & 1.58159 \\
\hline 32 & Slc7a11 & no definition & AK037490 & 1.57761 \\
\hline 33 & Ndrg1 & no definition & NM_008681 & 1.5652 \\
\hline 34 & Gprc5a & G protein-coupled receptor, family C, group 5, member A & NM_181444.3 & 1.51339 \\
\hline 35 & Ibrdc3 & no definition & XM_204030 & 1.49816 \\
\hline 36 & Ngf & nerve growth factor, beta & NM_013609.1 & 1.48619 \\
\hline 37 & Lce1d & late cornified envelope 1D & NM_027137.2 & 1.44977 \\
\hline 38 & Tpsab1 & tryptase alpha/beta 1 & NM_031187.2 & 1.44267 \\
\hline 39 & Htr2b & 5-hydroxytryptamine (serotonin) receptor $2 \mathrm{~B}$ & NM_008311.2 & 1.43265 \\
\hline
\end{tabular}




\begin{tabular}{|c|c|c|c|c|}
\hline $\begin{array}{l}\text { Sort } \\
\text { Order }\end{array}$ & Gene Symbol & Definition & Accession & $\begin{array}{l}\log _{2} \text { fold change } \\
\text { R6 vs. Ctrl }\end{array}$ \\
\hline 40 & Sox4 & SRY-box containing gene 4 & NM_009238.2 & 1.41763 \\
\hline 41 & $\| 1 \mathrm{rl} 1$ & interleukin 1 receptor-like 1 (IIrl1), transcript variant 1 & NM_001025602.1 & 1.3994 \\
\hline 42 & Prr9 & RIKEN cDNA A030004J04 gene (A030004J04Rik) & NM_175424.3 & 1.36416 \\
\hline 43 & Vgf & VGF nerve growth factor inducible & NM_001039385.1 & 1.35246 \\
\hline 44 & Errfi1 & ERBB receptor feedback inhibitor 1 & NM_133753.1 & 1.34582 \\
\hline 45 & 116 & interleukin 6 & NM_031168.1 & 1.33283 \\
\hline 46 & Gprc5a & no definition & NM_181444 & 1.31955 \\
\hline 47 & Antxr2 & anthrax toxin receptor 2 & NM_133738.1 & 1.30719 \\
\hline 48 & Tgif1 & TGFB-induced factor homeobox 1 & NM_009372.2 & 1.29814 \\
\hline 49 & Krt8 & keratin 8 & NM_031170.2 & 1.28819 \\
\hline 50 & 2300009A05Rik & $\begin{array}{l}\text { PREDICTED: RIKEN cDNA 2300009A05 gene, transcript } \\
\text { variant } 3\end{array}$ & XM_898537.2 & 1.26684 \\
\hline 51 & Dppa5a & developmental pluripotency associated 5 & NM_025274.1 & 1.258 \\
\hline 52 & Mt2 & metallothionein 2 & NM_008630.2 & 1.2441 \\
\hline 53 & Plaur & plasminogen activator, urokinase receptor & NM_011113.3 & 1.22553 \\
\hline 54 & Thbd & thrombomodulin & NM_009378.2 & 1.22252 \\
\hline 55 & LOC100047353 & PREDICTED: similar to myocardial vascular inhibition factor & XM_001477963.1 & 1.22053 \\
\hline 56 & Csf2 & colony stimulating factor 2 (granulocyte-macrophage) & NM_009969.4 & 1.22019 \\
\hline 57 & Map2k1 & mitogen-activated protein kinase kinase 1 & NM_008927.3 & 1.21788 \\
\hline 58 & Dpp7 & dipeptidylpeptidase 7 & NM_031843.2 & 1.21624 \\
\hline 59 & LOC672274 & PREDICTED: similar to Transcription factor SOX-4 & XR_003788.1 & 1.21149 \\
\hline 60 & Blcap & bladder cancer associated protein homolog & NM_016916.3 & 1.21046 \\
\hline 61 & Zfc3h1 & no definition & NM_001033261.2 & 1.20585 \\
\hline 62 & Dusp6 & dual specificity phosphatase 6 & NM_026268.1 & 1.20441 \\
\hline 63 & Areg & amphiregulin & NM_009704.3 & 1.19656 \\
\hline 64 & C630022N07Rik & no definition & no accession & 1.19569 \\
\hline 65 & Denr & density-regulated protein & NM_026603.1 & 1.18464 \\
\hline 66 & Slc3a2 & $\begin{array}{l}\text { solute carrier family } 3 \text { (activators of dibasic and neutral } \\
\text { amino acid transport), member } 2\end{array}$ & NM_008577.3 & 1.18244 \\
\hline 67 & Ern1 & endoplasmic reticulum (ER) to nucleus signalling 1 & NM_023913.2 & 1.15145 \\
\hline 68 & Dnmt3l & $\begin{array}{l}\text { DNA (cytosine-5-)-methyltransferase 3-like (Dnmt3l), } \\
\text { transcript variant } 2\end{array}$ & NM_001081695.1 & 1.13992 \\
\hline 69 & D130007C19Rik & no definition & AK051152 & 1.13724 \\
\hline 70 & LOC100046401 & PREDICTED: similar to SDR2 & XR_032583.1 & 1.1332 \\
\hline 71 & Sh3bp2 & SH3-domain binding protein 2 & NM_011893.2 & 1.11999 \\
\hline 72 & Tgoln1 & trans-golgi network protein & NM_009443.3 & 1.11454 \\
\hline 73 & Gm12226 & similar to oxidative stress responsive 1 (Rp23-297j14.5) & NM_001099322.1 & 1.11231 \\
\hline 74 & Stk40 & no definition & NM_028800 & 1.11149 \\
\hline 75 & Marcksl1 & MARCKS-like 1 (Marcksl1), mRNA. & NM_010807.3 & 1.09791 \\
\hline 76 & Ypel5 & yippee-like 5 (Drosophila) (Ypel5), mRNA. & NM_027166.3 & 1.08882 \\
\hline
\end{tabular}




\begin{tabular}{|c|c|c|c|c|}
\hline $\begin{array}{l}\text { Sort } \\
\text { Order }\end{array}$ & Gene Symbol & Definition & Accession & $\begin{array}{l}\log _{2} \text { fold change } \\
\text { R6 vs. Ctrl }\end{array}$ \\
\hline 77 & Fam180a & No definition & NM_173375 & 1.08779 \\
\hline 78 & Creb312 & $\begin{array}{l}\text { cAMP responsive element binding protein 3-like } 2 \text { (Creb3l2), } \\
\text { mRNA. }\end{array}$ & NM_178661.3 & 1.08689 \\
\hline 79 & Ly96 & lymphocyte antigen 96 (Ly96), mRNA. & NM_016923.1 & 1.06285 \\
\hline 80 & Igf2bp2 & $\begin{array}{l}\text { insulin-like growth factor } 2 \text { mRNA binding protein } 2 \text { (Igf2bp2), } \\
\text { mRNA. }\end{array}$ & NM_183029.1 & 1.06145 \\
\hline 81 & Mafg & $\begin{array}{l}\text { v-maf musculoaponeurotic fibrosarcoma oncogene family, } \\
\text { protein G }\end{array}$ & NM_010756.3 & 1.05594 \\
\hline 82 & Cttnbp2nl & No definition & NM_030249 & 1.04697 \\
\hline 83 & Col20a1 & PREDICTED: collagen, type XX, alpha 1 (Col20a1), mRNA. & XM_181390.5 & 1.04143 \\
\hline 84 & Vps37b & vacuolar protein sorting 37B (yeast) (Vps37b), mRNA. & NM_177876.4 & 1.03812 \\
\hline 85 & A530046M15 & No definition & XM_488663 & 1.03773 \\
\hline 86 & Eid3 & EP300 interacting inhibitor of differentiation 3 (Eid3), mRNA. & NM_025499.2 & 1.03567 \\
\hline 87 & Nabp1 & $\begin{array}{l}\text { oligonucleotide/oligosaccharide-binding fold containing 2A } \\
\text { (Obfc2a), mRNA. }\end{array}$ & NM_028696.2 & 1.0351 \\
\hline 88 & Pqlc1 & PQ loop repeat containing 1 (Pqlc1), mRNA. & NM_025861.2 & 1.03363 \\
\hline 89 & Whrn & whirlin (Whrn), transcript variant 6, mRNA. & NM_001008795.1 & 1.0255 \\
\hline 90 & Cish & cytokine inducible $\mathrm{SH}$-containing protein (Cish), mRNA. & NM_009895.3 & 1.02328 \\
\hline 91 & Ptpre & $\begin{array}{l}\text { protein tyrosine phosphatase, receptor type, E (Ptpre), } \\
\text { mRNA. }\end{array}$ & NM_011212.2 & 1.01915 \\
\hline 92 & Bach1 & BTB and CNC homology 1 (Bach1), mRNA. & NM_007520.2 & 1.01808 \\
\hline 93 & Cyb5r1 & cytochrome b5 reductase 1 (Cyb5r1), mRNA. & NM_028057.2 & 1.01401 \\
\hline 94 & Slc1a4 & $\begin{array}{l}\text { solute carrier family } 1 \text { (glutamate/neutral amino acid } \\
\text { transporter), member } 4\end{array}$ & NM_018861.2 & 1.00471 \\
\hline 95 & Mmd & no definition & AK033889 & 0.998067 \\
\hline 96 & Slc6a9 & $\begin{array}{l}\text { solute carrier family } 6 \text { (neurotransmitter transporter, } \\
\text { glycine), member } 9\end{array}$ & NM_008135.4 & 0.994683 \\
\hline 97 & LOC100047963 & PREDICTED: similar to ADIR1 & XM_001479238.1 & 0.994667 \\
\hline 98 & Atf4 & activating transcription factor 4 & NM_009716.2 & 0.982833 \\
\hline 99 & Cttnbp2nl & CTTNBP2 N-terminal like & NM_030249.3 & 0.970113 \\
\hline 100 & Mmp9 & matrix metallopeptidase 9 & NM_013599.2 & 0.968853 \\
\hline 101 & Hmga1 & high mobility group AT-hook 1 & NM_016660.2 & 0.96846 \\
\hline 102 & Phlda1 & pleckstrin homology-like domain, family A, member 1 & NM_009344.1 & 0.963867 \\
\hline 103 & Aars & alanyl-tRNA synthetase & NM_146217.3 & 0.962397 \\
\hline 104 & Angpt2 & angiopoietin 2 & NM_007426.3 & 0.95926 \\
\hline 105 & Zswim4 & zinc finger, SWIM domain containing 4 & NM_172503.3 & 0.957373 \\
\hline 106 & Selk & no definition & NM_019979.1 & 0.954917 \\
\hline 107 & Abhd2 & abhydrolase domain containing 2 & NM_018811.6 & 0.954587 \\
\hline 108 & Krtap4-16 & predicted gene, OTTMUSG00000002196 & NM_001013823.1 & 0.95438 \\
\hline 109 & Atg12 & autophagy-related 12 & NM_026217.1 & 0.94998 \\
\hline
\end{tabular}


Table 3. List of top 50 down-regulated genes at $6^{\text {th }}$ hour (R6) of anastasis, with $\log _{2}$ fold change $<-0.95$, compared with Ctrl (untreated cells).

\begin{tabular}{|c|c|c|c|c|}
\hline $\begin{array}{l}\text { Sort } \\
\text { Order }\end{array}$ & Gene Symbol & Definition & Accession & $\begin{array}{l}\log _{2} \text { fold change } \\
\text { (R6 vs. Ctrl) }\end{array}$ \\
\hline 1 & Hist1h2ak & histone cluster 1 , H2ak & NM_178183.1 & -1.91761 \\
\hline 2 & Hist1h2ag & histone cluster 1, H2ag & NM_178186.2 & -1.76767 \\
\hline 3 & Hist1h2ap & histone cluster $1, \mathrm{H} 2 \mathrm{ao}$ & NM_178185.1 & -1.7396 \\
\hline 4 & Hist1h2af & histone cluster 1 , H2af & NM_175661.1 & -1.6854 \\
\hline 5 & Hist2h2ac & histone cluster 2, H2ac & NM_175662.1 & -1.6272 \\
\hline 6 & Slc1a3 & $\begin{array}{l}\text { solute carrier family } 1 \text { (glial high affinity glutamate } \\
\text { transporter), member } 3\end{array}$ & NM_148938.2 & -1.61827 \\
\hline 7 & 9930013L23Rik & no definition & AK018112 & -1.59264 \\
\hline 8 & Hist1h2ah & histone cluster 1, H2ah & NM_175659.1 & -1.57002 \\
\hline 9 & Hist1h2al & PREDICTED: predicted gene, EG667728 & XR_035278.1 & -1.56907 \\
\hline 10 & Hist1h2ad & histone cluster $1, \mathrm{H} 2 \mathrm{ad}$ & NM_178188.3 & -1.56233 \\
\hline 11 & Scel & sciellin & NM_022886.2 & -1.48845 \\
\hline 12 & Hist1h2ai & histone cluster 1, H2ai & NM_178182.1 & -1.40187 \\
\hline 13 & Fzd2 & frizzled homolog 2 & NM_020510.2 & -1.38203 \\
\hline 14 & Sdpr & serum deprivation response & NM_138741.1 & -1.38033 \\
\hline 15 & Hs3st1 & heparan sulfate (glucosamine) 3-O-sulfotransferase 1 & NM_010474.1 & -1.32418 \\
\hline 16 & Hist2h2ab & histone cluster 2, H2ab & NM_178213.3 & -1.30977 \\
\hline 17 & Kif2c & kinesin family member 2C (Kif2c) XM_986361 & NM_134471.3 & -1.21821 \\
\hline 18 & Fam198b & RIKEN cDNA $1110032 E 23$ gene (1110032E23Rik) & NM_133187.2 & -1.1988 \\
\hline 19 & Cdc42ep2 & CDC42 effector protein (Rho GTPase binding) 2 & NM_026772.1 & -1.19681 \\
\hline 20 & Lurap1l & $\begin{array}{l}\text { DNA segment, Chr 4, Brigham \& Women's Genetics } \\
0951 \text { expressed (D4Bwg0951e) }\end{array}$ & NM_026821.4 & -1.18656 \\
\hline 21 & Medag & RIKEN cDNA 6330406I15 gene & NM_027519.1 & -1.18243 \\
\hline 22 & Disp1 & dispatched homolog 1 & NM_026866.2 & -1.18107 \\
\hline 23 & Bmp4 & bone morphogenetic protein 4 & NM_007554.2 & -1.16637 \\
\hline 24 & Rab27a & RAB27A, member RAS oncogene family & NM_023635.4 & -1.13917 \\
\hline 25 & Aurka & aurora kinase $\mathrm{A}$ & NM_011497.3 & -1.12507 \\
\hline 26 & Ncaph & non-SMC condensin I complex, subunit $\mathrm{H}$ & NM_144818.1 & -1.12132 \\
\hline 27 & Fignl1 & fidgetin-like 1 & NM_021891.2 & -1.10521 \\
\hline 28 & $\mathrm{Dbp}$ & D site albumin promoter binding protein & NM_016974.1 & -1.09945 \\
\hline 29 & Meis2 & Meis homeobox 2 (Meis2), transcript variant 2 & NM_010825.2 & -1.08487 \\
\hline 30 & Synpo & PREDICTED: synaptopodin, transcript variant 2 & XM_981156.1 & -1.08076 \\
\hline 31 & Hist1h2an & histone cluster 1, H2an & NM_178184.1 & -1.0804 \\
\hline 32 & Fam111a & RIKEN cDNA 4632417K18 gene (4632417K18Rik) & NM_026640.2 & -1.07617 \\
\hline 33 & Aurkb & aurora kinase B & NM_011496.1 & -1.07507 \\
\hline 34 & Anln & anillin, actin binding protein & NM_028390.2 & -1.07218 \\
\hline 35 & Tuft1 & tuftelin 1 & NM_011656.2 & -1.06969 \\
\hline 36 & Cxcl12 & $\begin{array}{l}\text { chemokine (C-X-C motif) ligand } 12 \text { (Cxcl12), } \\
\text { transcript variant } 1\end{array}$ & NM_021704.2 & -1.0664 \\
\hline 37 & Sipa111 & signal-induced proliferation-associated 1 like 1 & NM_172579.1 & -1.03567 \\
\hline 38 & Rbms2 & $\begin{array}{l}\text { RNA binding motif, single stranded interacting } \\
\text { protein } 2\end{array}$ & NM_019711.2 & -1.03096 \\
\hline 39 & Wdr6 & WD repeat domain 6 & NM_031392.2 & -1.02705 \\
\hline 40 & Tk1 & thymidine kinase 1 & NM_009387.1 & -1.02669 \\
\hline 41 & Mylk & myosin, light polypeptide kinase & NM_139300.3 & -1.01621 \\
\hline
\end{tabular}




\begin{tabular}{|c|c|c|c|c|}
\hline $\begin{array}{l}\text { Sort } \\
\text { Order }\end{array}$ & Gene Symbol & Definition & Accession & $\begin{array}{l}\log _{2} \text { fold change } \\
\text { (R6 vs. Ctrl) }\end{array}$ \\
\hline 42 & Slc9a3r1 & $\begin{array}{l}\text { solute carrier family } 9 \text { (sodium/hydrogen } \\
\text { exchanger), member } 3 \text { regulator } 1\end{array}$ & NM_012030.2 & -1.0137 \\
\hline 43 & Kif22 & kinesin family member 22 & NM_145588.1 & -1.01346 \\
\hline 44 & Speer3 & $\begin{array}{l}\text { spermatogenesis associated glutamate (E)-rich } \\
\text { protein } 3\end{array}$ & NM_027650.2 & -1.01229 \\
\hline 45 & Mrgprf & MAS-related GPR, member F & NM_145379.2 & -1.01038 \\
\hline 46 & Bub1b & $\begin{array}{l}\text { budding uninhibited by benzimidazoles } 1 \text { homolog, } \\
\text { beta }\end{array}$ & NM_009773.1 & -1.00547 \\
\hline 47 & Pcgf5 & polycomb group ring finger 5 & NM_029508.3 & -1.00513 \\
\hline 48 & Marcks & myristoylated alanine rich protein kinase $\mathrm{C}$ substrate & NM_008538.2 & -0.973133 \\
\hline 49 & Fam83d & 2310007D09Rik & NM_027975.1 & -0.966323 \\
\hline 50 & Slc16a4 & $\begin{array}{l}\text { solute carrier family } 16 \text { (monocarboxylic acid } \\
\text { transporters), member } 4\end{array}$ & NM_146136.1 & -0.96461 \\
\hline
\end{tabular}

The change in transcriptional profiles during anastasis provides us mechanistic insights into how dying cells could reverse apoptosis (Figure 4). In early anastasis (R3), our microarray data reveals that the regulators of the TGF- $\beta$ signalling pathway, which control various fundamental cellular process, including proliferation, cell survival, apoptosis and transformation ${ }^{53-55}$, are upregulated. The activation of the TGF- $\beta$ pathway is further supported by the upregulation of AP-1 (Jun-Fos) during early anastasis. The up-regulation of the TGF- $\beta$ pathway also promote the expression of murine double minute $2(\mathrm{Mdm} 2)^{56,57}$, an inhibitor of p53 that is also up-regulated during early anastasis ${ }^{27}$. As p53 plays a critical role in regulating apoptosis and DNA repair ${ }^{58,59}$, the expression of Mdm2 could not only promote cell survival by inhibiting p53mediated cell death, but also cause mutations as we have observed in the cells after anastasis ${ }^{27}$. Expression of Mdm2 can also activate $\mathrm{XIAP}^{60}$, which inhibits caspases 3, 7 and $9^{61-66}$, and therefore, could promote anastasis by suppressing the caspase-mediated cell destruction process. Up-regulation of anti-apoptotic BCL2 protein (Bag3) and heat shock proteins (Hsps) during anastasis can also neutralize pro-apoptotic proteins to promote cell recovery ${ }^{67-69}$. Notably, Bbc3 is a pro-apoptotic BH3-only gene to encode PUMA (p53 upregulated modulator of apoptosis) ${ }^{70,71}$. Its expression peaks at anastasis (R3-R6), suggesting the sign of anastasis vs apoptosis in the recovering cells during the early stage of the cell recovery process.

To reverse apoptosis, the recovering cells need to remove or recycle the destroyed cellular components, such as the toxic or damaged proteins that are cleaved by caspases, and dysfunctional organelles like the permeabilized mitochondria. Autophagy could contribute to anastasis, as the recovering cells display up-regulation of Atg12 (Figure 3B, Table 2), which is important to the formation of autophagosome to engulf the materials that are then transported to lysosomes or vacuoles for degradation ${ }^{72-75}$. Recently studies reveal that autophagy can be activated by the DNA damage response, and play a role in maintaining the nuclear and mitochondrial genomic integrity through DNA repair and removal of micronuclei and damaged nuclear parts ${ }^{76,77}$. This could suppress mutagenesis and oncogenic transformation to occur in the cells that reverse apoptosis as observed after DNA damage ${ }^{27,28}$. Autophagy is also implicated in the exosome secretory pathway ${ }^{78-80}$, which could allow rapid clearance of damaged or toxic materials during anastasis through exosomes. Interestingly, our microarray data shows that the recovering cells display up-regulation of potent angiogenic factors such as Vegfa and Angptl4 (Figure 3A and B, Table 1 and Table 2), which promote vascular permeability and angiogenesis $^{81-84}$. This could facilitate anastasis by supplying nutrient and clearing waste products. However, this could also enhance tumour progression and metastasis when anastasis occurs cancer cells. In fact, our data also reveals the up-regulation of genes involved in cell migration during anastasis ${ }^{27}$, such as Mmp 10 and 13 that encode matrix metalloproteinases ${ }^{85-88}$. This could be a stressinducible response that promotes cell migration, like what was observed in HeLa cells after anastasis ${ }^{28}$, which might contribute to wound healing, or metastasis during cancer recurrence ${ }^{89,90}$.

Arresting cell cycle during anastasis is important as it can allow damaged cells to be repaired before they restore proliferation. This hypothesis is supported by the microarray data that reveals up-regulation of genes that suppress cell cycle (Figure 3A-C). For example, B-cell translocation gene $1(\mathrm{Btg} 1)$ is an anti-proliferative gene $^{91,92}$, which is up-regulated during the early anastasis (R3). At later stage of anastasis (R6), other cell cycle inhibitors express, including Cdkn1a which encodes p21 that induces cell cycle arrest and senescence ${ }^{93-95}$, and also Trp53inp1 which encodes tumor protein p53-inducible nuclear protein 1 that can arrest cycle independent to p53 expression ${ }^{96}$. These suggest that cell cycle is suppressed by multiple pathways during anastasis. 


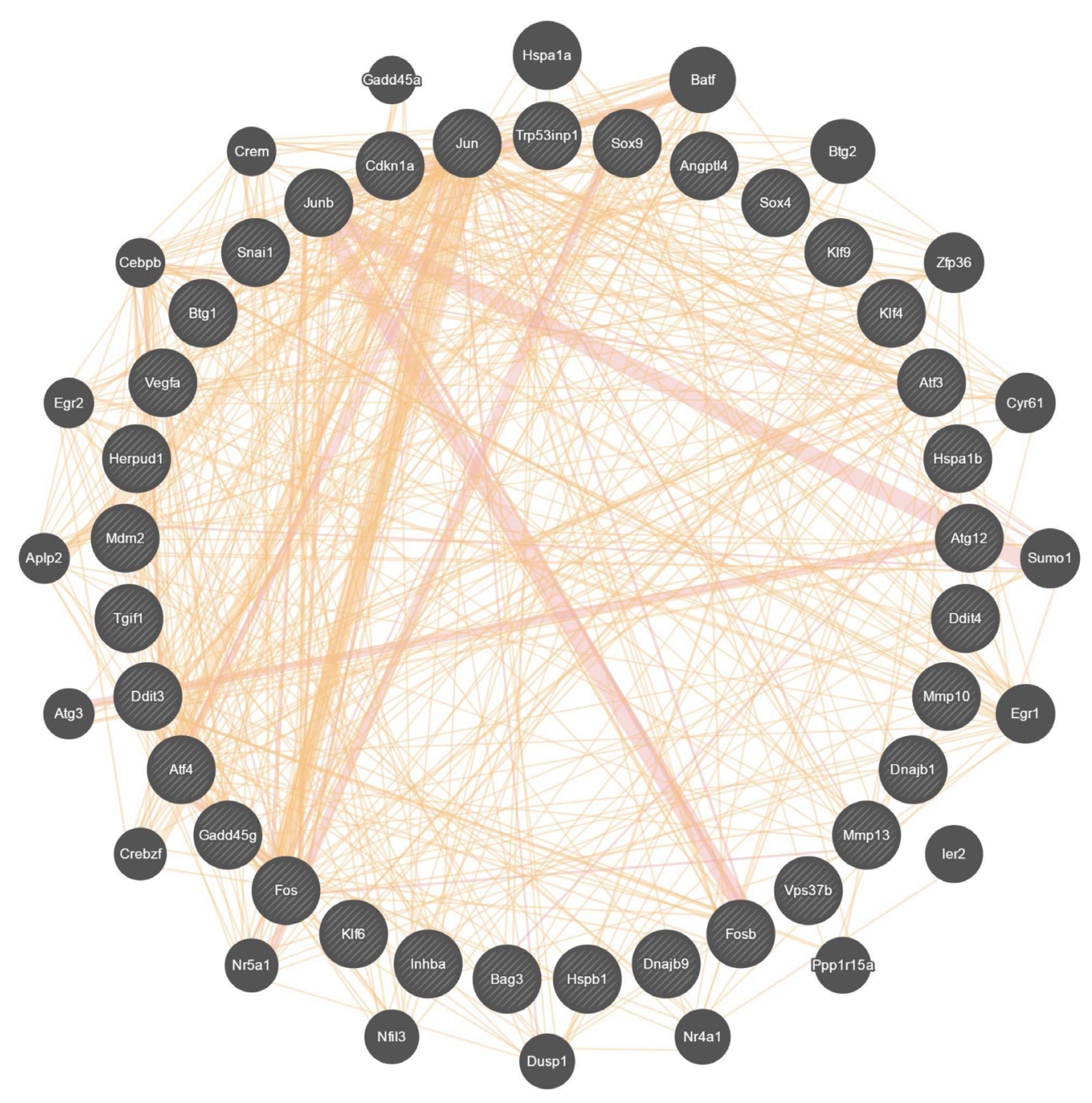

Input gene

Related gene

Physical interactions

Predicted interactions

Figure 4. Interaction network of the up-regulated genes during anastasis. The 33 up-regulated genes during anastasis were selected for analysis using GeneMANIA.

We also identified genes that are up-regulated both during apoptosis and anastasis, such as Gadd45g, and Rnu6 (Figure 3C, Table 4). Gadd45g functions in growth arrest and DNA repair ${ }^{97,98}$, and therefore, could be the cytoprotective mechanism that preserves the dying cells during cell death induction (R0), and promotes the injured cells to repair when environment is improved (R3 and R6). Rnu6 encodes U6 small nuclear RNA, which is important for splicing of a mammalian pre-mRNA ${ }^{99-102}$. Upregulation of Rnu6 from R0 to R6 suggests that post-transcription regulation could involve during apoptosis and anastasis. In fact, translational regulation also contributes to anastasis. For example, caspase-3, PARP and ICAP are cleaved in dying cells during apoptosis, and the non-cleaved form of corresponding proteins restores after anastasis (Figure 1B). Interestingly, the mRNA level of caspase-3 and PARP did not show significant increase (see Data availability ${ }^{52}$ ). This suggests translational regulation to occur during anastasis. 
Table 4. List of top 15 up-regulated genes during apoptosis (R0) and anastasis (R3 and R6), with log fold change $>1$ either on R0, R3, or R6, compared with Ctrl (untreated cells).

\begin{tabular}{|c|c|c|c|c|c|c|c|}
\hline \multirow[b]{2}{*}{$\begin{array}{l}\text { Sort } \\
\text { Order }\end{array}$} & \multirow[b]{2}{*}{ Gene Symbol } & \multirow[b]{2}{*}{ Definition } & \multirow[b]{2}{*}{ Accession } & \multicolumn{4}{|c|}{$\log _{2}$ fold change } \\
\hline & & & & RO vs. Ctrl & R3 vs. Ctrl & R6 vs. Ctrl & R24 vs. Ctrl \\
\hline 1 & Rnu6 & U6 small nuclear RNA & NR_003027.1 & 2.75163 & 2.08117 & 1.63203 & 0.315967 \\
\hline 2 & Med23 & no definition & AK042346 & 2.53792 & 2.37555 & 1.87041 & 0.70258 \\
\hline 3 & Prf1 & perforin 1 & NM_011073.2 & 2.40981 & 2.36444 & 1.1381 & 0.262567 \\
\hline 4 & F830002E14Rik & no definition & AK089567 & 2.18787 & 0.549207 & 0.731387 & -0.08211 \\
\hline 5 & Slc11a1 & $\begin{array}{l}\text { solute carrier family } \\
11 \text { (proton-coupled } \\
\text { divalent metal ion } \\
\text { transporters), member } 1\end{array}$ & NM_013612.1 & 1.51837 & 2.24547 & 1.50337 & 0.53101 \\
\hline 6 & Hist1h4a & histone cluster 1, H4a & NM_178192.1 & 1.46352 & 1.19978 & 0.87087 & 0.08441 \\
\hline 7 & Hist1h4j & histone cluster $1, \mathrm{H} 4 \mathrm{j}$ & NM_178210.1 & 1.4276 & 1.15198 & 0.801933 & 0.241233 \\
\hline 8 & 2310005L22Rik & no definition & no accession & 1.19244 & 1.23574 & 0.79319 & 0.0878833 \\
\hline 9 & 2810026P18Rik & no definition & no accession & 1.12393 & 1.14743 & 0.527953 & -0.31585 \\
\hline 10 & Gadd45g & $\begin{array}{l}\text { growth arrest and } \\
\text { DNA-damage-inducible } \\
45 \text { gamma }\end{array}$ & NM_011817.1 & 1.04177 & 1.85013 & 1.0444 & -0.324567 \\
\hline 11 & Sppl3 & no definition & AK047886 & 1.01269 & 1.85284 & 1.22205 & 0.51878 \\
\hline 12 & 1810026B05Rik & no definition & XM_489186 & 0.9892 & 0.92441 & 0.742947 & -0.257843 \\
\hline 13 & BC030476 & $\begin{array}{l}\text { cDNA sequence } \\
\text { BC030476 }\end{array}$ & NM_173421.1 & 0.98391 & 1.51116 & 0.495447 & 0.2612 \\
\hline 14 & Zbtb2 & $\begin{array}{l}\text { zinc finger and BTB } \\
\text { domain containing } 2\end{array}$ & $\begin{array}{l}\mathrm{NM}_{-} \\
001033466.1\end{array}$ & 0.882457 & 1.25171 & 0.253943 & -0.116403 \\
\hline 15 & Ppp1r15a & $\begin{array}{l}\text { myeloid differentiation } \\
\text { primary response } \\
\text { gene } 116\end{array}$ & NM_008654.1 & 0.862993 & 2.48696 & 1.82011 & -0.25323 \\
\hline
\end{tabular}

Our study provides new insights into the mechanisms and consequences of anastasis (Figure 5) Researchers can analyse our microarray data to further identify the hallmarks of anastasis, understand its role, elucidate molecular mechanisms that reverse apoptosis, and develop therapeutic strategies to control anastasis. To identify the genes that displace specific change on a transcriptional level, software such as Spotfire can be used to view the gene expression pattern at different time points during the reversal of apoptosis ${ }^{49}$. To study the molecular mechanism of anastasis, Ingenuity Pathway Analysis can be used to create mechanistic hypotheses according to the transcriptional profile ${ }^{103}$. To identify drugs that modulate anastasis, Connectivity Map can be used to identify small molecules that promote or suppress anastasis based on its gene expression signature ${ }^{104,105}$. Anastasis could be a cell survival phenomenon mediated by multiple pathways ${ }^{26-28,30}$, so by comparing the gene expression profiles, researchers can study its potential connection to other cellular processes, such as antiapoptotic pathways, autophagy, and stress-inducible responses ${ }^{75,106-110}$. By searching the molecular signature of anastasis, researchers can study the potential contribution to physiopathological conditions, such as metastasis during cancer recurrence, recovery from heart failure and wound healing ${ }^{89,90,111}$. Further data analysis will stimulate generation of hypotheses for future studies involving anastasis. As our understanding of anastasis mechanism expands, it will uncover its potential impacts on physiology and pathology, and offer exciting new therapeutic opportunities to intractable diseases by mediating cell death and survival (Figure 6).

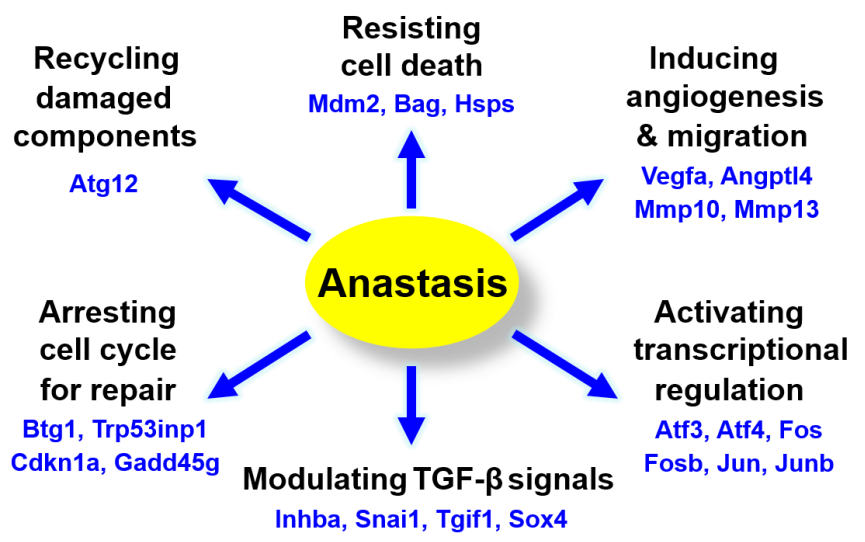

Figure 5. Up-regulation of genes and potential corresponding pathways during reversal of apoptosis. 


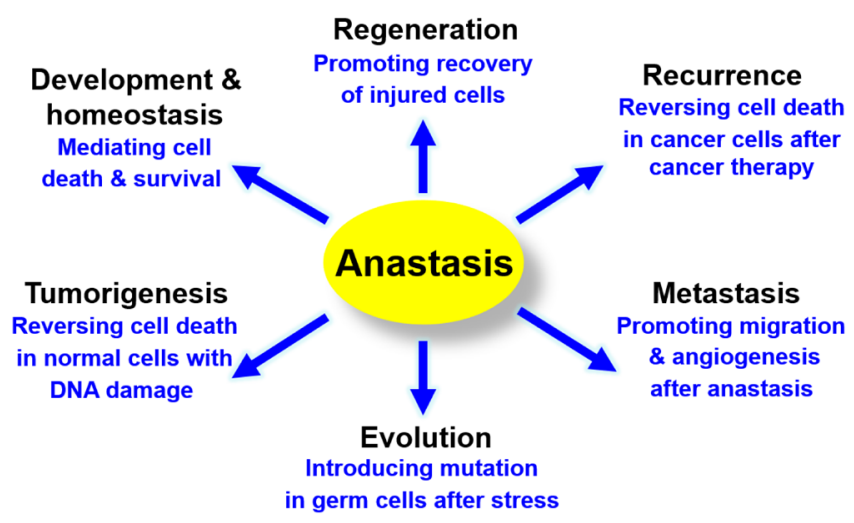

Figure 6. Potential consequences of anastasis.

\section{Data availability}

Raw data for Tang et al., 2016 "Molecular signature of anastasis for reversal of apoptosis" available at: doi, 10.6084/ m9.figshare. $4502732^{52}$

(http://dx.doi.org/10.6084/m9.figshare.4502732)
Author contributions

H.L.T., H.M.T. and M.C.F. conceived the idea and designed the research; H.L.T. and H.M.T. wrote the article, conducted the analyses together with C.T.J. and M.C.F. All authors agreed to the final content of the manuscript.

\section{Competing interests}

No competing interests were disclosed.

\section{Grant information}

This work was supported by the Life Science Research Foundation fellowship (H.L.T.).

The funders had no role in study design, data collection and analysis, decision to publish, or preparation of the manuscript.

\section{Acknowledgements}

We thank J. Marie Hardwick for valuable advice to this work, and the Johns Hopkins Deep Sequencing and Microarray Core Facility for data analysis. Ho Lam Tang is a Shurl and Kay Curci Foundation Fellow of the Life Sciences Research Foundation.

\section{Supplementary material}

Supplementary Figure 1: Genes display unique expression patterns at each timepoint. Output of all genes analysed by Spotfire (K cluster, also see Data availability ${ }^{52}$ ).

\section{Click here to access the data.}

1. Kerr JF, Wyllie AH, Currie AR: Apoptosis: a basic biological phenomenon with wide-ranging implications in tissue kinetics. Br J Cancer. 1972; 26(4): 239-57. PubMed Abstract | Publisher Full Text | Free Full Text

2. Riedl SJ, Shi Y: Molecular mechanisms of caspase regulation during apoptosis. Nat Rev Mol Cell Biol. 2004; 5(11): 897-907. PubMed Abstract | Publisher Full Text

3. Green DR, Kroemer G: The pathophysiology of mitochondrial cell death Science. 2004; 305(5684): 626-9. PubMed Abstract | Publisher Full Text

4. Chipuk JE, Bouchier-Hayes L, Green DR: Mitochondrial outer membrane permeabilization during apoptosis: the innocent bystander scenario. $\mathrm{Cell}$ Death Differ. 2006; 13(8): 1396-402. PubMed Abstract | Publisher Full Text

5. Kroemer G, Galluzzi L, Vandenabeele P, et al:: Classification of cell death: recommendations of the Nomenclature Committee on Cell Death 2009. Cell Death Differ. 2009; 16(1): 3-11.

PubMed Abstract | Publisher Full Text | Free Full Text

6. Galluzzi L, Vitale I, Abrams JM, et al:: Molecular definitions of cell death subroutines: recommendations of the Nomenclature Committee on Cell Death 2012. Cell Death Differ. 2012; 19(1): 107-20.

PubMed Abstract | Publisher Full Text | Free Full Text

7. Holland AJ, Cleveland DW: Chromoanagenesis and cancer: mechanisms and consequences of localized, complex chromosomal rearrangements. Nat Med. 2012; 18(11): 1630-8.

PubMed Abstract | Publisher Full Text | Free Full Text
8. Wang X: The expanding role of mitochondria in apoptosis. Genes Dev. 2001; 15(22): 2922-33. PubMed Abstract

9. Galluzzi L, Kepp O, Kroemer G: Mitochondria: master regulators of danger signalling. Nat Rev Mol Cell Biol. 2012; 13(12): 780-8.

PubMed Abstract | Publisher Full Text

10. Du C, Fang M, Li Y, et al.: Smac, a mitochondrial protein that promotes cytochrome c-dependent caspase activation by eliminating IAP inhibition. Cell. 2000; 102(1): 33-42.

PubMed Abstract | Publisher Full Text

11. Verhagen AM, Ekert PG, Pakusch M, et al:: Identification of DIABLO, a mammalian protein that promotes apoptosis by binding to and antagonizing IAP proteins. Cell. 2000; 102(1): 43-53. PubMed Abstract | Publisher Full Text

12. Susin SA, Lorenzo HK, Zamzami N, et al:: Molecular characterization of mitochondrial apoptosis-inducing factor. Nature. 1999; 397(6718): 441-6. PubMed Abstract | Publisher Full Text

13. Miramar MD, Costantini $P$, Ravagnan L, et al.: NADH oxidase activity of mitochondrial apoptosis-inducing factor. J Biol Chem. 2001; 276(19): 16391-8. PubMed Abstract | Publisher Full Text

14. Joza N, Susin SA, Daugas E, et al.: Essential role of the mitochondrial apoptosis-inducing factor in programmed cell death. Nature. 2001; 410(6828): 549-54. PubMed Abstract | Publisher Full Text

15. Li LY, Luo X, Wang X: Endonuclease $G$ is an apoptotic DNase when released 
from mitochondria. Nature. 2001; 412(6842): 95-9 PubMed Abstract | Publisher Full Text

16. Lüthi AU, Martin SJ: The CASBAH: a searchable database of caspase substrates. Cell Death Differ. 2007; 14(4): 641-50. PubMed Abstract | Publisher Full Text

17. Liu X, Zou H, Slaughter C, et al:: DFF, a heterodimeric protein that functions downstream of caspase-3 to trigger DNA fragmentation during apoptosis. Cell. 1997; 89(2): 175-84.

PubMed Abstract | Publisher Full Text

18. Enari M, Sakahira H, Yokoyama $\mathrm{H}$, et al:: A caspase-activated DNase that degrades DNA during apoptosis, and its inhibitor ICAD. Nature. 1998; 391(6662): 43-50. PubMed Abstract | Publisher Full Text

19. Mukae N, Enari M, Sakahira $\mathrm{H}$, et al:: Molecular cloning and characterization of human caspase-activated DNase. Proc Natl Acad Sci U S A. 1998; 95(16): 9123-8.

PubMed Abstract | Publisher Full Text | Free Full Text

20. Coleman ML, Sahai EA, Yeo M, et al:: Membrane blebbing during apoptosis results from caspase-mediated activation of ROCK I. Nat Cell Biol. 2001; 3(4): 339-45.

PubMed Abstract | Publisher Full Text

21. Orlando KA, Stone NL, Pittman RN: Rho kinase regulates fragmentation and phagocytosis of apoptotic cells. Exp Cell Res. 2006; 312(1): 5-15. PubMed Abstract | Publisher Full Text

22. Tyas L, Brophy VA, Pope A, et al:: Rapid caspase-3 activation during apoptosis revealed using fluorescence-resonance energy transfer. EMBO Rep. 2000; 1(3): 266-70.

PubMed Abstract | Publisher Full Text | Free Full Text

23. Takemoto K, Nagai T, Miyawaki A, et al:: Spatio-temporal activation of caspase revealed by indicator that is insensitive to environmental effects. J Cell Biol. 2003; 160(2): 235-43.

PubMed Abstract | Publisher Full Text | Free Full Text

24. Hammill AK, Uhr JW, Scheuermann RH: Annexin V staining due to loss of membrane asymmetry can be reversible and precede commitment to apoptotic death. Exp Cell Res. 1999; 251(1): 16-21. PubMed Abstract | Publisher Full Text

25. Geske FJ, Lieberman R, Strange R, et al.: Early stages of p53-induced apoptosis are reversible. Cell Death Differ. 2001; 8(2): 182-91. PubMed Abstract | Publisher Full Text

26. Tang $\mathrm{HL}$, Yuen $\mathrm{KL}$, Tang $\mathrm{HM}$, et al:: Reversibility of apoptosis in cancer cells. Br J Cancer. 2009; 100(1): 118-22.

PubMed Abstract | Publisher Full Text | Free Full Text

27. Tang HL, Tang HM, Mak KH, et al.: Cell survival, DNA damage, and oncogenic transformation after a transient and reversible apoptotic response. Mol Biol Cell. 2012; 23(12): 2240-52.

PubMed Abstract | Publisher Full Text | Free Full Text

28. Tang HL, Tang HM, Hardwick JM, et al:: Strategies for tracking anastasis, a cell survival phenomenon that reverses apoptosis. J Vis Exp. 2015; (96). PubMed Abstract | Publisher Full Text

29. Ichim G, Lopez J, Ahmed SU, et al.: Limited mitochondrial permeabilization causes DNA damage and genomic instability in the absence of cell death. Mo Cell. 2015; 57(5): 860-72.

PubMed Abstract | Publisher Full Text | Free Full Text

30. Tang HL, Tang HM, Fung MC, et al.: In vivo CaspaseTracker biosensor system for detecting anastasis and non-apoptotic caspase activity. Sci Rep. 2015; 5: 9015

PubMed Abstract | Publisher Full Text | Free Full Text

31. Ding AX, Sun G, Argaw YG, et al:: CasExpress reveals widespread and diverse patterns of cell survival of caspase-3 activation during development in vivo. eLife. 2016; 5: pii: e10936.

PubMed Abstract | Publisher Full Text | Free Full Text

32. Taylor RC, Cullen SP, Martin SJ: Apoptosis: controlled demolition at the cellular level. Nat Rev Mol Cell Biol. 2008; 9(3): 231-41. PubMed Abstract | Publisher Full Text

33. Davis AJ, Tannock JF: Repopulation of tumour cells between cycles of chemotherapy: a neglected factor. Lancet Oncol. 2000; 1(2): 86-93. PubMed Abstract | Publisher Full Text

34. Kim JJ, Tannock IF: Repopulation of cancer cells during therapy: an important cause of treatment failure. Nat Rev Cancer. 2005; 5(7): 516-25. PubMed Abstract | Publisher Full Text

35. Wagle N, Emery C, Berger MF, et al.: Dissecting therapeutic resistance to RAF inhibition in melanoma by tumor genomic profiling. J Clin Oncol. 2011; 29(22): 3085-96.

PubMed Abstract | Publisher Full Text | Free Full Text

36. Manjila S, Ray A, Hu Y, et al:: Embryonal tumors with abundant neuropil and true rosettes: 2 illustrative cases and a review of the literature. Neurosurg Focus. 2011; 30(1): E2

PubMed Abstract | Publisher Full Text

37. Boffetta P, Hashibe M: Alcohol and cancer. Lancet Oncol. 2006; 7(2): 149-56. PubMed Abstract | Publisher Full Tex

38. McKillop IH, Schrum LW: Alcohol and liver cancer. Alcohol. 2005; 35(3): 195-203. PubMed Abstract | Publisher Full Text

39. Castellsagué X, Muñoz N, De Stefani E, et al.: Influence of mate drinking, hot beverages and diet on esophageal cancer risk in South America. Int J Cancer 2000; 88(4): 658-64.

PubMed Abstract | Publisher Full Text

40. Islami F, Pourshams A, Nasrollahzadeh D, et al.: Tea drinking habits and oesophageal cancer in a high risk area in northern Iran: population based case-control study. BMJ. 2009; 338: b929.

PubMed Abstract | Publisher Full Text | Free Full Text

41. Loomis D, Guyton KZ, Grosse Y, et al:: Carcinogenicity of drinking coffee, mate, and very hot beverages. Lancet Oncol. 2016; 17(7): 877-8.

PubMed Abstract | Publisher Full Text

42. Smith RE, Bryant J, DeCillis A, et al.: Acute myeloid leukemia and myelodysplastic syndrome after doxorubicin-cyclophosphamide adjuvant therapy for operable breast cancer: the National Surgical Adjuvant Breast and Bowel Project Experience. J Clin Oncol. 2003; 21(7): 1195-204. PubMed Abstract | Publisher Full Text

43. Travis LB, Fosså SD, Schonfeld SJ, et al:: Second cancers among 40,576 testicular cancer patients: focus on long-term survivors. $J$ Natl Cancer Inst. 2005; 97(18): 1354-65

PubMed Abstract | Publisher Full Tex

44. Chaturvedi AK, Engels EA, Gilbert ES, et al: Second cancers among 104,760 survivors of cervical cancer: evaluation of long-term risk. J Natl Cancer Inst. 2007; 99(21): 1634-43.

PubMled Abstract | Publisher Full Text

45. Cowell IG, Austin CA: Mechanism of generation of therapy related leukemia in response to anti-topoisomerase II agents. Int J Environ Res Public Health. 2012; 9(6): 2075-91.

PubMed Abstract | Publisher Full Text | Free Full Text

46. Kenis $\mathrm{H}$, Zandbergen HR, Hofstra L, et al.: Annexin A5 uptake in ischemic myocardium: demonstration of reversible phosphatidylserine externalization and feasibility of radionuclide imaging. J Nucl Med. 2010; 51(2): 259-67. PubMed Abstract | Publisher Full Text

47. Zurlo J, Arterburn LM: Characterization of a primary hepatocyte culture system for toxicological studies. In Vitro Cell Dev Biol Anim. 1996; 32(4): 211-20. PubMed Abstract | Publisher Full Text

48. Downey $\mathrm{T}$ : Analysis of a multifactor microarray study using Partek genomics solution. Methods Enzymol. 2006; 411: 256-70.

PubMed Abstract | Publisher Full Text

49. Kaushal D, Naeve CW: An overview of Spotfire for gene-expression studies. Curr Protoc Hum Genet. 2005; Chapter 11: Unit 119. PubMed Abstract | Publisher Full Text

50. Warde-Farley D, Donaldson SL, Comes O, et al:: The GeneMANIA prediction server: biological network integration for gene prioritization and predicting gene function. Nucleic Acids Res. 2010; 38(Web Server issue): W214-20. PubMed Abstract | Publisher Full Text | Free Full Text

51. Zuberi K, Franz M, Rodriguez H, et al.: GeneMANIA prediction server 2013 update. Nucleic Acids Res. 2013; 41(Web Server issue): W115-22. PubMed Abstract | Publisher Full Text | Free Full Text

52. Tang HL, Tang HM, Fung MC, et al:: Molecular signature of anastasis for reversal of apoptosis. Figshare. 2016

Data Source

53. Massagué J: How cells read TGF-beta signals. Nat Rev Mol Cell Biol. 2000; 1(3): 169-78.

PubMed Abstract | Publisher Full Text

54. Massagué J: TGF- $\beta$ signaling in development and disease. FEBS Lett. 2012; 586(14): 1833

PubMed Abstract | Publisher Full Text

55. Siegel PM, Massagué J: Cytostatic and apoptotic actions of TGF-beta in homeostasis and cancer. Nat Rev Cancer. 2003; 3(11): 807-21. PubMed Abstract | Publisher Full Text

56. Oliner JD, Kinzler KW, Meltzer PS, et al: Amplification of a gene encoding a p53-associated protein in human sarcomas. Nature. 1992; 358(6381): 80-3. PubMed Abstract | Publisher Full Text

57. Araki S, Eitel JA, Batuello CN, et al:: TGF-beta1-induced expression of human Mdm2 correlates with late-stage metastatic breast cancer. J Clin Invest. 2010; 120(1): 290-302.

PubMed Abstract | Publisher Full Text | Free Full Text

58. Lakin ND, Jackson SP: Regulation of p53 in response to DNA damage. Oncogene. 1999; 18(53): 7644-55.

PubMed Abstract | Publisher Full Text

59. Wade M, Li YC, Wahl GM: MDM2, MDMX and p53 in oncogenesis and cancer therapy. Nat Rev Cancer. 2013; 13(2): 83-96. PubMed Abstract | Publisher Full Text | Free Full Tex

60. Gu L, Zhu N, Zhang $\mathrm{H}$, et al:: Regulation of XIAP translation and induction by MDM2 following irradiation. Cancer Cell. 2009; 15(5): 363-75. PubMed Abstract | Publisher Full Text | Free Full Text

61. Sun $\mathrm{C}, \mathrm{Cai} \mathrm{M}$, Gunasekera $\mathrm{AH}$, et al.: NMR structure and mutagenesis of the inhibitor-of-apoptosis protein XIAP. Nature. 1999; 401(6755): 818-22. PubMed Abstract | Publisher Full Text

62. Chai J, Shiozaki E, Srinivasula SM, et al.: Structural basis of caspase-7 inhibition by XIAP. Cell. 2001; 104(5): 769-80. PubMed Abstract | Publisher Full Tex

63. Huang Y, Park YC, Rich RL, et al:: Structural basis of caspase inhibition by XIAP: differential roles of the linker versus the BIR domain. Cell. 2001; 104(5): 
$781-90$

PubMed Abstract | Publisher Full Text

64. Riedl SJ, Renatus M, Schwarzenbacher R, et al:: Structural basis for the inhibition of caspase-3 by XIAP. Cell. 2001; 104(5): 791-800.

PubMed Abstract | Publisher Full Text

65. Srinivasula SM, Hegde R, Saleh A, et al:: A conserved XIAP-interaction motif in caspase-9 and Smac/DIABLO regulates caspase activity and apoptosis. Nature. 2001; 410(6824): 112-6.

PubMed Abstract | Publisher Full Text

66. Shiozaki EN, Chai J, Rigotti DJ, et al.: Mechanism of XIAP-mediated inhibition of caspase-9. Mol Cell. 2003; 11(2): 519-27.

PubMed Abstract | Publisher Full Text

67. Chipuk JE, Moldoveanu T, Llambi F, et al.: The BCL-2 family reunion. Mol Cell. 2010; 37(3): 299-310.

PubMed Abstract | Publisher Full Text | Free Full Text

68. Richter K, Haslbeck M, Buchner J: The heat shock response: life on the verge of death. Mol Cell. 2010; 40(2): 253-66. PubMed Abstract | Publisher Full Tex

69. Kampinga $\mathrm{HH}$, Bergink $\mathrm{S}$ : Heat shock proteins as potential targets for protective strategies in neurodegeneration. Lancet Neurol. 2016; 15(7): 748-59. PubMed Abstract | Publisher Full Text

70. Han J, Flemington $\mathrm{C}$, Houghton $\mathrm{AB}$, et al.: Expression of $\boldsymbol{b b c 3}$, a pro-apoptotic $\mathrm{BH} 3-$ only gene, is regulated by diverse cell death and survival signals. Proc Natl Acad Sci U S A. 2001; 98(20): 11318-23.

PubMed Abstract | Publisher Full Text | Free Full Text

71. Nakano K, Vousden KH: PUMA, a novel proapoptotic gene, is induced by p53. Mol Cell. 2001; 7(3): 683-94.

PubMed Abstract | Publisher Full Text

72. Mizushima N, Noda T, Yoshimori T, et al:: A protein conjugation system essential for autophagy. Nature. 1998; 395(6700): 395-8.

PubMed Abstract | Publisher Full Text

73. Mizushima N, Komatsu M: Autophagy: renovation of cells and tissues. Cell. $2011 ; 147(4): 728-41$

PubMed Abstract | Publisher Full Text

74. Walczak M, Martens S: Dissecting the role of the Atg12-Atg5-Atg16 complex during autophagosome formation. Autophagy. 2013; 9(3): 424-5. PubMed Abstract | Publisher Full Text | Free Full Text

75. Farré JC, Subramani S: Mechanistic insights into selective autophagy pathways: lessons from yeast. Nat Rev Mol Cell Biol. 2016; 17(9): 537-52. PubMed Abstract | Publisher Full Text

76. Vessoni AT, Filippi-Chiela EC, Menck CF, et al:: Autophagy and genomic integrity. Cell Death Differ. 2013; 20(11): 1444-54.

PubMed Abstract | Publisher Full Text | Free Full Text

77. Hewitt G, Korolchuk VI: Repair, Reuse, Recycle: The Expanding Role of Autophagy in Genome Maintenance. Trends Cell Biol. 2016; pii: S09628924(16)30209-4.

PubMed Abstract | Publisher Full Text

78. Settembre C, Fraldi A, Medina DL, et al.: Signals from the lysosome: a contro centre for cellular clearance and energy metabolism. Nat Rev Mol Cell Biol. 2013; 14(5): 283-96.

PubMed Abstract | Publisher Full Text | Free Full Text

79. Desdín-Micó G, Mittelbrunn M: Role of exosomes in the protection of cellular homeostasis. Cell Adh Migr. 2016; 1-8. PubMed Abstract | Publisher Full Tex

80. Papandreou ME, Tavernarakis N: Autophagy and the endo/exosomal pathways in health and disease. Biotechnol J. 2016. PubMed Abstract | Publisher Full Text

81. Ferrara N, Gerber HP, LeCouter J: The biology of VEGF and its receptors. Nat Med. 2003; 9(6): 669-76.

PubMed Abstract | Publisher Full Text

82. Simons M, Gordon E, Claesson-Welsh L: Mechanisms and regulation of endothelial VEGF receptor signalling. Nat Rev Mol Cell Biol. 2016; 17(10): 611-25. PubMed Abstract | Publisher Full Text

83. Babapoor-Farrokhran S, Jee K, Puchner B, et al:: Angiopoietin-like 4 is a potent angiogenic factor and a novel therapeutic target for patients with proliferative diabetic retinopathy. Proc Natl Acad Sci U S A. 2015; 112(23): E3030-9. PubMed Abstract | Publisher Full Text | Free Full Text

84. Guo L, Li SY, Ji FY, et al.: Role of Angptl4 in vascular permeability and inflammation. Inflamm Res. 2014; 63(1): 13-22. PubMed Abstract | Publisher Full Text

85. Nabeshima K, Inoue T, Shimao Y, et al:: Matrix metalloproteinases in tumor invasion: role for cell migration. Pathol Int. 2002; 52(4): 255-64. PubMed Abstract | Publisher Full Text

86. Bonnans $\mathrm{C}$, Chou J, Werb Z: Remodelling the extracellular matrix in development and disease. Nat Rev Mol Cell Biol. 2014; 15(12): 786-801. PubMed Abstract | Publisher Full Text | Free Full Text

87. Paul CD, Mistriotis $\mathrm{P}$, Konstantopoulos $\mathrm{K}$ : Cancer cell motility: lessons from migration in confined spaces. Nat Rev Cancer. 2016. PubMed Abstract | Publisher Full Text
88. Mittal R, Patel AP, Debs LH, et al.: Intricate Functions of Matrix Metalloproteinases in Physiological and Pathological Conditions. J Cell Physiol. 2016; 231(12): 2599-621.

PubMed Abstract | Publisher Full Text

89. Steeg PS: Targeting metastasis. Nat Rev Cancer. 2016; 16(4): 201-18. PubMed Abstract | Publisher Full Text

90. Eming SA, Martin P, Tomic-Canic M: Wound repair and regeneration: mechanisms, signaling, and translation. Sci Transl Med. 2014; 6(265): 265sr6. PubMed Abstract | Publisher Full Text | Free Full Text

91. Matsuda S, Rouault $\mathrm{J}$, Magaud J, et al:: In search of a function for the TIS21/PC3/ BTG1/TOB family. FEBS Lett. 2001; 497(2-3): 67-72.

PubMed Abstract | Publisher Full Text

92. Winkler GS: The mammalian anti-proliferative BTG/Tob protein family. J Cell Physiol. 2010; 222(1): 66-72.

PubMed Abstract | Publisher Full Text

93. Gartel AL, Radhakrishnan SK: Lost in transcription: p21 repression, mechanisms, and consequences. Cancer Res. 2005; 65(10): 3980-5. PubMed Abstract | Publisher Full Text

94. Cazzalini O, Scovassi Al, Savio M, et al.: Multiple roles of the cell cycle inhibitor p21 ${ }^{\text {CDKN1A }}$ in the DNA damage response. Mutat Res. 2010; 704(1-3): 12-20. PubMed Abstract | Publisher Full Text

95. Muñoz-Espín D, Serrano M: Cellular senescence: from physiology to pathology Nat Rev Mol Cell Biol. 2014; 15(7): 482-96.

PublMed Abstract | Publisher Full Text

96. Tomasini R, Seux M, Nowak J, et al.: TP53INP1 is a novel p73 target gene that induces cell cycle arrest and cell death by modulating p73 transcriptional activity. Oncogene. 2005; 24(55): 8093-104. PubMed Abstract | Publisher Full Text

97. Azam N, Vairapandi M, Zhang W, et al:: Interaction of CR6 (GADD45gamma ) with proliferating cell nuclear antigen impedes negative growth control. $J$ Biol Chem. 2001; 276(4): 2766-74.

PubMed Abstract | Publisher Full Text

98. Niehrs C, Schäfer A: Active DNA demethylation by Gadd45 and DNA repair. Trends Cell Biol. 2012; 22(4): 220-7.

PubMed Abstract | Publisher Full Text

99. Ohshima $\mathrm{Y}$, Okada N, Tani $\mathrm{T}$, et al.: Nucleotide sequences of mouse genomic loci including a gene or pseudogene for U6 (4.8S) nuclear RNA. Nucleic Acids Res. 1981; 9(19): 5145-58.

PubMed Abstract | Publisher Full Text | Free Full Text

100. Wu JA, Manley JL: Base pairing between U2 and U6 snRNAs is necessary for splicing of a mammalian pre-mRNA. Nature. 1991; 352(6338): 818-21. PubMed Abstract | Publisher Full Text

101. Datta B, Weiner AM: Genetic evidence for base pairing between U2 and U6 snRNA in mammalian mRNA splicing. Nature. 1991; 352(6338): 821-4. PubMed Abstract | Publisher Full Text

102. Yean SL, Wuenschell G, Termini J, et al.: Metal-ion coordination by U6 small nuclear RNA contributes to catalysis in the spliceosome. Nature. 2000; 408(6814): 881-4

PubMed Abstract | Publisher Full Text | Free Full Text

103. Krämer A, Green J, Pollard J Jr, et al:: Causal analysis approaches in Ingenuity Pathway Analysis. Bioinformatics. 2014; 30(4): 523-30. PubMed Abstract | Publisher Full Text | Free Full Text

104. Lamb J, Crawford ED, Peck D, et al.: The Connectivity Map: using geneexpression signatures to connect small molecules, genes, and disease. Science. 2006; 313(5795): 1929-35. PublMed Abstract | Publisher Full Text

105. Lamb J: The Connectivity Map: a new tool for biomedical research. Nat Rev Cancer. 2007; 7(1): 54-60.

PubMed Abstract | Publisher Full Text

106. Fuchs $\mathrm{Y}$, Steller $\mathrm{H}$ : Live to die another way: modes of programmed cell death and the signals emanating from dying cells. Nat Rev Mol Cell Biol. 2015; 16(6): 329-44.

PubMed Abstract | Publisher Full Text | Free Full Text

107. Kruiswijk F, Labuschagne $\mathrm{CF}$, Vousden $\mathrm{KH}$ : p53 in survival, death and metabolic health: a lifeguard with a licence to kill. Nat Rev Mol Cell Biol. 2015; 16(7): 393-405. PubMed Abstract | Publisher Full Text

108. Wang J, Zhang J, Lee YM, et al: Quantitative chemical proteomics profiling of de novo protein synthesis during starvation-mediated autophagy. Autophagy. 2016; 12(10): 1931-1944.

PubMed Abstract | Publisher Full Text | Free Full Text

109. Füllgrabe J, Klionsky DJ, Joseph B: The return of the nucleus: transcriptional and epigenetic control of autophagy. Nat Rev Mol Cell Biol. 2014; 15(1): 65-74. PubMed Abstract | Publisher Full Text

110. Hetz C: The unfolded protein response: controlling cell fate decisions under ER stress and beyond. Nat Rev Mol Cell Biol. 2012; 13(2): 89-102. PubMed Abstract | Publisher Full Text

111. Narula J, Haider N, Arbustini E, et al.: Mechanisms of disease: apoptosis in heart failure--seeing hope in death. Nat Clin Pract Cardiovasc Med. 2006; 3(12): 681-8. PubMed Abstract | Publisher Full Text 


\section{Open Peer Review}

\section{Current Peer Review Status:}

\section{Version 1}

Reviewer Report 30 January 2017

https://doi.org/10.5256/f1000research.11388.r19503

(C) 2017 Liu S. This is an open access peer review report distributed under the terms of the Creative Commons Attribution License, which permits unrestricted use, distribution, and reproduction in any medium, provided the original work is properly cited.

\section{Sanzhen Liu}

Department of Plant Pathology, Kansas State University, Manhattan, KS, USA

The manuscript by Tang et al. was focused on the elucidation of the molecular mechanisms of an important phenomenon, anastasis, through time-course expression profiling. Anastasis was recently discovered and has not been fully studied yet. It's molecular basis remains to be uncovered. The study provided useful information to better understand this underexplored process. Overall, the experiment was well designed. The time course experiment included six time points, untreated samples as the control, toxin-induced apoptosis, and four time points after removal of toxin. Three biological replicates were performed at each time point. Figure 1 illustrated the experimental design very well. The biological interpretation of microarray results is reasonable. The reviewer has no major concerns. However, several minor changes are needed, especially for the presentation of figures, which could be improved.

First, no multiple test correction was mentioned in the microarray analysis section. It was described that the $p$-value less than 0.05 was used to declare statistical significance. The reviewer would suggest the authors confirm that. A false discovery rate (FDR) method is needed for multiple test correction.

Second, the PCA result from Figure 2A showed that three biological replicates were closely clustered, which showed a good repeatability. However, the goal of PCA is not just check the repeatability of three replicates of each group (time point). PCA can be also used to examine the relationship among groups. My recommendation is that the authors provide more description for the PCA result. In addition, in Figure 2A, the percentage of PC2 explaining total variation was masked. But based on the value of PC3, it should be greater than $5.89 \%$. Given the high value of PC1, I would suggest plotting a two dimension PCA plot to display the result or re-plotting this three-dimension plot.

Third, it would be useful to list the number of significant differential expression for each comparison. And I guess the clustering result in Figure 3 presented all significant genes.

Figure 4 showed some interesting result about gene interactions. I did not see enough description 
about this figure in the main text.

Editorial comments:

In the Abstract, "whole genome" can be replaced by "genome-wide".

Competing Interests: No competing interests were disclosed.

I confirm that I have read this submission and believe that I have an appropriate level of expertise to confirm that it is of an acceptable scientific standard.

Reviewer Report 20 January 2017

https://doi.org/10.5256/f1000research.11388.r19354

(c) 2017 Miyamoto T. This is an open access peer review report distributed under the terms of the Creative Commons Attribution License, which permits unrestricted use, distribution, and reproduction in any medium, provided the original work is properly cited.

\section{Takafumi Miyamoto}

University of Tokyo, Tokyo, Japan

This study unravels the gene regulatory network that seems to be involved in the process of anastasis. It is interesting that the authors found various genes that appear to participate in ethanol-induced anastasis, suggesting that the dynamic reconstitution of gene regulatory networks might be a prerequisite for rescuing cells from the brink of cell death. Overall, this work is worth being indexed. However, I would like to see the following points in the research addressed, before approval:

1. Anastasis is a developing concept rather than an established one. It would be better to show the expression dynamics of caspase-3, PARP, and ICAD at all analyzed time points (Cont, R0, R3, R6, R24, and R48). In addition, why don't the authors show apoptotic DNA fragmentation to make sure that all the analyzed cells in the anastasis stage definitely underwent apoptosis?

2. I may have missed noting this, but there is no statistical analysis of the gene expression changes observed in the microarray data. In Fig. 2B, the expression levels of several genes seem different in the same time point replicates. It would be better to show the genes that were induced or suppressed during anastasis, along with the statistical significance of the differences.

3. Given the importance of understanding the mechanism of anastasis, it would be better to verify the data obtained from microarray analysis, by using quantitative PCR or Western blotting.

Competing Interests: No competing interests were disclosed.

I confirm that I have read this submission and believe that I have an appropriate level of 


\section{expertise to confirm that it is of an acceptable scientific standard, however I have significant reservations, as outlined above.}

\section{Author Response 03 Feb 2017}

Ho Lam Tang, Johns Hopkins University Bloomberg School of Public Health, Baltimore, USA

We thank for the enthusiasm and valuable input from the reviewer, and have made the following changes:

1. We have included the Western blot data (Figure 1B), which shows that caspase-3, PARP and ICAD were cleaved during apoptosis, but then recovered to their original level at 24 hours after removal of the cell death stimulus. Interestingly, our microarray data shows that their level of mRNA remained no significant change at all time points $(3,6,24$ and 48 hours) after removal of the cell death stimulus, compared with the untreated (control) cells (data available at figshare, please see Data availability in the manuscript), suggesting the recovery of corresponding proteins is contributed by the regulation of translation during and after anastasis. The related data and discussion are included in our revised manuscript.

Our earlier studies using time-lapse live cell microscopy and comic assay demonstrated that the current apoptotic induction (4.5\% ethanol, 5 hours) can trigger DNA damage. After removal of the stimulus, major of the dying cells can recover. Interestingly, some cells that reversed apoptosis display chromosomal abnormality and oncogenic transformation, indicating reversibility of apoptosis after DNA damage. In our current study, we further found significant reduction of mRNA level of multiple histone genes during anastasis. Notably, cellular levels of histones reduce in response to DNA damage, as to enhance DNA repairing. Therefore, reduction of expression of histones during anastasis could be a sign of cells that recover from DNA damage after apoptosis.

2. We have included supplementary data with corresponding $p$-value for statistical significance of fold change for all of the 3 biological replicants of each gene (see Data availability). The software for the microarray data analysis is mentioned at the "Materials and methods" section.

3. We have verified our data by RT-PCR in human liver cancer HepG2 cell line, and included the data in the new Figure 4.

Competing Interests: No competing interests were disclosed. 
The benefits of publishing with F1000Research:

- Your article is published within days, with no editorial bias

- You can publish traditional articles, null/negative results, case reports, data notes and more

- The peer review process is transparent and collaborative

- Your article is indexed in PubMed after passing peer review

- Dedicated customer support at every stage

For pre-submission enquiries, contact research@f1000.com 